\title{
The Microbiome and Its Implications in Cancer Immunotherapy
}

\author{
Hani Choudhry
}

check for

updates

Citation: Choudhry, H. The

Microbiome and Its Implications in Cancer Immunotherapy. Molecules 2021, 26, 206. https://doi.org/ 10.3390/molecules26010206

Academic Editors: Ferdinando Nicoletti, Amedeo Amedei and Elena Niccolai

Received: 29 November 2020 Accepted: 30 December 2020

Published: 3 January 2021

Publisher's Note: MDPI stays neutral with regard to jurisdictional clai$\mathrm{ms}$ in published maps and institutional affiliations.

Copyright: $\odot 2021$ by the author. Licensee MDPI, Basel, Switzerland. This article is an open access article distributed under the terms and conditions of the Creative Commons Attribution (CC BY) license (https:// creativecommons.org/licenses/by/ $4.0 /)$.
Department of Biochemistry, Faculty of Sciences, Cancer and Mutagenesis Unit, King Fahd Medical Research Center, King Abdulaziz University, Jeddah 21589, Saudi Arabia; hchaudahry@kau.edu.sa

\begin{abstract}
Cancer is responsible for $\sim 18$ million deaths globally each year, representing a major cause of death. Several types of therapy strategies such as radiotherapy, chemotherapy and more recently immunotherapy, have been implemented in treating various types of cancer. Microbes have recently been found to be both directly and indirectly involved in cancer progression and regulation, and studies have provided novel and clear insights into the microbiome-mediated emergence of cancers. Scientists around the globe are striving hard to identify and characterize these microbes and the underlying mechanisms by which they promote or suppress various kinds of cancer. Microbes may influence immunotherapy by blocking various cell cycle checkpoints and the production of certain metabolites. Hence, there is an urgent need to better understand the role of these microbes in the promotion and suppression of cancer. The identification of microbes may help in the development of future diagnostic tools to cure cancers possibly associated with the microbiome. This review mainly focuses on various microbes and their association with different types of cancer, responses to immunotherapeutic modulation, physiological responses, and prebiotic and postbiotic effects.
\end{abstract}

Keywords: microbiome; cancer progression and microbes; physiological responses; CTLA-4; immunotherapy; immuno-oncology

\section{Introduction}

The microbiome refers to the total collection of trillions of microbes, such as bacteria, fungi, and viruses that are living in the human body. The presence of microbes can be beneficial or harmful to health. Microbes that are not pathogenic assist in digestion and the production of vitamins such as $\mathrm{K}, \mathrm{A}$, and $\mathrm{E}$ in addition to releasing certain enzymes and producing other useful byproducts such as acids. The major microbes are found in the intestinal tract and colon followed by skin and vagina [1]. These microbes have been evolved along with human beings as part of an evolutionary phenomenon characterized by processes lasting many years [2]. The development of the intestinal microbiome starts at a very early stage during childhood, through intimate interactions of the microbiome associated with the maternal body [3]. This ecology of the microbiomeis basically affected by the diet consumed by the mother, gestational age, delivery type, and exposure to various antibiotics [4]. Both types of innate and adaptive immune systems have intimate associations with the microbiome that continuously resides in the human intestine [5]. Recent studies have demonstrated that the intestinal microbiome plays very critical role in the regulation of human homeostasis and the immune system, and can probably causeshuman metabolic disorders, including cancer [6]. Studies have shown that commensal microbes are useful in supporting the immune system through inhibiting inflammatory responses and eliciting Toll-like receptors (TLR) responses [7]. The intestine is the site for the absorption of nutrients and other important metabolites. The metabolites of microbiota are also absorbed in the intestine and ultimately assimilate into the bloodstream. Once assimilated into the bloodstream, these metabolites start to associate with G-protein coupled receptors [8] and ultimately contribute to the regulation of human physiology and pathogenesis. Therefore, the gut microbiome is also called the human's second brain. The GBA (gut-brain axis) works as a two-way flow of important information and signaling between the systems of 
the brain and the microbiome [9]. The gut microbiome has a great impact on the heart and its related diseases, the regulation of glucose metabolism, insulin sensitivity; andhuman energy homeostasis [10]. The microbiome is also associated with inflammatory pathways, lipid metabolism and the initiating obesity through genetic and epigenetic crosstalk [11]. The gut microbiota also affects mood fluctuations, especially in cases of depression and anxiety [12]. $10 \times 10^{6}$.

The role of microbes in cancer initiation and progression have not been clearly ascertained yet. Some microbes have been broadly studied in certain cancer types, e.g., the presence of F. bravibacterium has been reported in colon cancer. Firmicutes and Enterobacteriaceae have been widely characterized in the case of gut cancer [13,14]. Different types of cancer have been reported to have different kinds of microbes (bacteria and viruses). Recent advances in metagenomics and transcriptomics analysis have made it easy to recognize and characterize various microbiomes in related cancer and their role in increasing or inducing physiological changes. While an individual's microbiome in various types of cancer is supposed to be the same, environmental variations may lead to new kinds of microbes [15-19]. There is an urgent requirement to characterize microbes in healthy and diseased conditions. Correlations between these two conditions can help to trace the availability of microbes and the development of diagnostic tools for the targeted treatment of cancers. In this review, we summarize the microbes that are generally found to be associated with various types of cancer and the effect of immunotherapy on their microbiomes. In addition, the effect of probiotics and prebiotics on the role of microbes that play a role in disease and the associated physiological changes in the host and microbes will also be discussed.

\section{The Microbiome and Its Association with Various Kinds of Cancer}

The human gut has a diverse microbial ecosystem that includes viruses, fungi, archaea, and bacteria. Bacteria play a major role as microbiota and mostly belong to phyla Bacteroidetes, Proteobacteria, Firmicutes, and Actinobacteria. Microbes have been found to be involved and associated with 10-20\% types of human cancer (Figure 1). Efforts are being made to characterize microbes affecting cancer progression and inhibition, including in affecting responses to various treatments given to patients. In response to cancer progression, various microbes have been reported that causes disease, as shown in Table 1 [20-25]. Increment level of Escherichia coli, Staphylococcus bovis, Fusobacterium nucleatum, Clostridium spp., Streptococcus spp., and Bacteroides have been reported incolorectal cancer, while decrement in level of Lactobacillus, Microbacterium, Anoxybacillus, and Akkermansia muciniphila. A list of common cancers and their associated microbes is given in Table 1 [26-35]. The presence of microbes could be used as a bioindicator to ensure early detection and therefore treatment of disease at its early stages. A method to trace those microbes in response to disease should be devised [36-40]. Microbes need to be characterized in each kind of cancer, and proper control measures need to be devised for treatment [40-43]. Several microbes have been causally linked to various types of cancers, e.g., Helicobacter pylori are the major causative agent of gastric lymphoma, gastric adenocarcinoma, and esophageal adenocarcinoma, while the Epstein-Barr virus (EBV) causes lymphomas and nasopharyngeal carcinoma $[44,45]$. Other viruses have been reported to cause other types of liver and lymphatic cancers are shown in Table 2 [46]. Intestinal flora and its metabolites work as major causativeagents ofcolorectal cancer. Diverse flora present in the intestine are manyprobiotic microbes, namely Bifidobacterium, Streptococcus thermophilus, Lactobacillus rhamnosus and Lactobacillus acidophilus, in addition to pathogenic bacteria such as Enterococcus faecalis, Bacteroides fragilis, Clostridia, Fusobacterium nucleatum, Streptococcus bovis, Salmonella and Enterotoxigenic $[47,48]$. Therefore, proper screening and microbiome classification could further provide knowledge of disease occurrence and progression. 


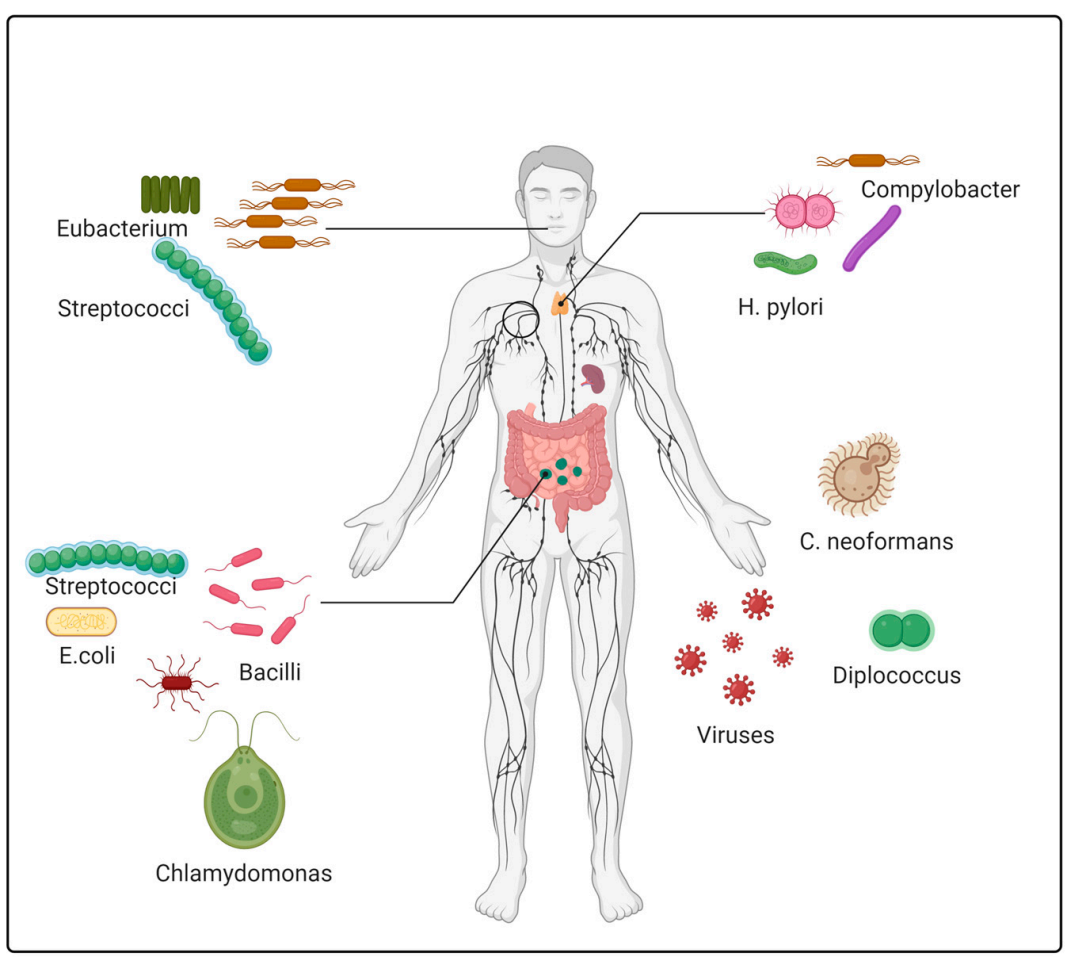

Figure 1. Human microbiomes of various organs. The human gut is a diverse microbial ecosystem comprising viruses, fungi, archaea, and bacteria. These microbiomes affect cancer progression and inhibition in response to various treatments given to patients.

Table 1. Microbiota changes reported in human cancer types.

\begin{tabular}{|c|c|c|c|}
\hline Type of Cancer & Sampling Location & $\begin{array}{c}\text { Microbial } \\
\text { Increase/Decrease }\end{array}$ & References \\
\hline Colorectal & $\begin{array}{l}\text { Biopsied tissue and } \\
\text { feces materials }\end{array}$ & $\begin{array}{l}\text { Increased: Escherichia coli, } \\
\text { Staphylococcus bovis, } \\
\text { Fusobacterium nucleatum, } \\
\text { Clostridium spp., } \\
\text { Streptococcus spp., and } \\
\text { Bacteroides. } \\
\text { Decreased: } \\
\text { Butyrate-producing bacteria, } \\
\text { Lactobacillus, Microbacterium, } \\
\text { Anoxybacillus, and } \\
\text { Akkermansia muciniphila. }\end{array}$ & [26-28] \\
\hline Gall bladder & Bile samples & $\begin{array}{l}\text { Increased: Salmonella } \\
\text { paratyphi and S. typhi; } \\
\text { Bile is typically considered to } \\
\text { be bacteria-free but is } \\
\text { infected in many cases. }\end{array}$ & {$[28,29]$} \\
\hline $\begin{array}{l}\text { Esophageal and } \\
\text { Barrett's esophagus }\end{array}$ & $\begin{array}{l}\text { Saliva sample and } \\
\text { biopsy tissue }\end{array}$ & $\begin{array}{l}\text { Increased: S. anginosus, } \\
\text { Treponema denticola, } \\
\text { Campylobacter concisus, C. } \\
\text { rectus and S. mitis. } \\
\text { Decreased: Helicobacter pylori. }\end{array}$ & [30-32] \\
\hline Mouth carcinoma & Saliva culture & $\begin{array}{l}\text { Increased: Eubacterium } \\
\text { sabureum, Leptotrichia buccalis, } \\
\text { C. ochracea, Capnocytophaga } \\
\text { gingivalis and } \\
\text { Streptococcus mitis }\end{array}$ & [33-35] \\
\hline
\end{tabular}


Table 2. Specific microbes (virus/bacteria) identified to cause various human cancers.

\begin{tabular}{|c|c|}
\hline Microbes & Type(s) of Cancer \\
\hline Human herpes virus 8 & Kaposi'ssarcoma \\
\hline $\begin{array}{l}\text { Type } 1 \text { human T-cell lymphotropic virus } \\
\text { (HTLV-1) }\end{array}$ & T-cell lymphoma, leukemia (adult) \\
\hline $\mathrm{Hb}-\mathrm{B}$ virus & Hepatocellular carcinoma \\
\hline $\mathrm{Hb}$-Cvirus & Lymphoma, hepatocellular carcinoma \\
\hline HIV (human immunodeficiency virus) & Kaposi's sarcoma, lymphomas \\
\hline EBV (Epstein-Barr virus) & Nasopharyngeal carcinoma, lymphomas \\
\hline HPV (human papilloma virus) & $\begin{array}{c}\text { Oropharyngeal carcinoma, anogenital } \\
\text { carcinomas }\end{array}$ \\
\hline Helicobacter pylori & $\begin{array}{l}\text { Esophageal adenocarcinoma, gastric } \\
\text { lymphoma, gastric adenocarcinoma }\end{array}$ \\
\hline
\end{tabular}

Tumor promoting or suppressing effects have also been reported in gastric, lung, liver, and colorectal cancer when microbes are present [49]. Germ-free models have shown less capabilities of tumors growth in comparison with microbe-associated models, as shown in Table 3 [50-60]. Each type of microbe needs to be characterized so that the early detection of cancer is possible for every type of disease. Table 3 [50-60] shows the murine models for various types of cancers and the treatments that were applied, and their results in terms of reduced tumor incidence in relation to the presence of germs.

Table 3. Several studies on murine models showing tumor-promoting effects of bacterial microbiota.

\begin{tabular}{clll}
\hline Cancer & \multicolumn{1}{c}{ Study Model } & \multicolumn{1}{c}{ Outcome/s } & References \\
\hline \multirow{2}{*}{ Mreast } & $\begin{array}{l}\text { Germ-free rats treated } \\
\text { with DMAB. }\end{array}$ & $\begin{array}{l}\text { Reduced tumors growth in } \\
\text { germ-free rats. }\end{array}$ & [50] \\
\hline \multirow{2}{*}{ Lung } & $\begin{array}{l}\text { Germ-free rats treated } \\
\text { with NHMI. }\end{array}$ & $\begin{array}{l}\text { Fewer tumors in male } \\
\text { germ-free rats. } \\
\text { No observed changes in } \\
\text { female germ-free rats. }\end{array}$ & [51] \\
\hline \multirow{5}{*}{ Gastric } & $\begin{array}{l}\text { 1. INS-GAS mice } \\
\text { (gnotobiotic) infected } \\
\text { with Helicobacter pylori. }\end{array}$ & $\begin{array}{l}\text { Fewer tumors in } \\
\text { germ-free mice. }\end{array}$ & [52] \\
\cline { 2 - 4 } & $\begin{array}{l}\text { 2. Antibiotic-treated } \\
\text { INS-GAS mice infected } \\
\text { with Helicobacter pylori. }\end{array}$ & $\begin{array}{l}\text { Fewer tumors in mice } \\
\text { treated with antibiotics. }\end{array}$ \\
\hline
\end{tabular}


Table 3. Cont.

\begin{tabular}{|c|c|c|c|}
\hline Cancer & Study Model & Outcome/s & References \\
\hline & Murine Studies & & \\
\hline \multirow{6}{*}{ Liver } & $\begin{array}{l}\text { 1. Germ-free mice treated } \\
\text { with }(\mathrm{DEN}) \text { and } \mathrm{CCl}_{4} \text {. }\end{array}$ & $\begin{array}{l}\text { Fewer tumors in } \\
\text { germ-free mice. }\end{array}$ & [53] \\
\hline & $\begin{array}{l}\text { 2. An antibiotic cocktail } \\
\text { was administered to DEN } \\
\text { and } \mathrm{CCl}_{4} \text {-treated mice. }\end{array}$ & $\begin{array}{l}\text { Fewer tumors in } \\
\text { antibiotic-treated mice. }\end{array}$ & {$[54]$} \\
\hline & $\begin{array}{l}\text { 3. Rifaximin } \\
\text { administered to DEN and } \\
\mathrm{CCl}_{4} \text {-treated mice. }\end{array}$ & $\begin{array}{l}\text { Fewer tumors in } \\
\text { rifaximin-treated mice. }\end{array}$ & [54] \\
\hline & $\begin{array}{l}\text { 4. Neomycin } \\
\text { administeredto } \\
\text { DEN-treated rats. }\end{array}$ & $\begin{array}{l}\text { Fewer tumors in } \\
\text { neomycin-treated rats. }\end{array}$ & {$[54]$} \\
\hline & $\begin{array}{l}\text { 5. Vancomycin } \\
\text { administeredto } \\
\text { DMBA-treated miceon a } \\
\text { high-fatdiet. }\end{array}$ & $\begin{array}{l}\text { Fewer tumors in } \\
\text { vancomycin-treated mice. }\end{array}$ & [55] \\
\hline & $\begin{array}{l}\text { 6. An antibiotic cocktail } \\
\text { administered to } \\
\text { DMBA-treated mice on a } \\
\text { high-fat diet. }\end{array}$ & $\begin{array}{l}\text { Fewer tumors in } \\
\text { antibiotic-treated mice. }\end{array}$ & [55] \\
\hline \multirow{6}{*}{ Colorectal } & $\begin{array}{l}\text { 1. Germ-free mice } \\
(\text { ApcMin/+). }\end{array}$ & $\begin{array}{l}\text { Fewer tumors in } \\
\text { germ-free mice. }\end{array}$ & {$[56]$} \\
\hline & $\begin{array}{l}\text { 2. Gnotobiotic mice } \\
\text { (AOM in } I L-10-/-) \text {. }\end{array}$ & $\begin{array}{l}\text { Fewer tumors in } \\
\text { germ-free mice. }\end{array}$ & [57] \\
\hline & $\begin{array}{l}\text { 3. Mice }(A p c \mathrm{Min} /+ \\
C d x 2-\mathrm{Cre}) \text { treated with an } \\
\text { antibiotic mixture. }\end{array}$ & $\begin{array}{l}\text { Fewer tumors in } \\
\text { antibiotic-treated mice. }\end{array}$ & [58] \\
\hline & $\begin{array}{l}\text { 4. Mice }(\text { Nod } 1-/-) \\
\text { treated with an antibiotic } \\
\text { mixture. }\end{array}$ & $\begin{array}{l}\text { Fewer tumors in } \\
\text { antibiotic-treated mice. }\end{array}$ & [59] \\
\hline & $\begin{array}{l}\text { 5. Mice (DSS and AOM) } \\
\text { treated with an antibiotic } \\
\text { mixture. }\end{array}$ & $\begin{array}{l}\text { Fewer tumors in } \\
\text { antibiotic-treated mice. }\end{array}$ & {$[60]$} \\
\hline & $\begin{array}{l}\text { 6. Mice }(\operatorname{Nod} 2-/-) \text { were } \\
\text { transplanted with } \\
\text { wild-type microbiota. }\end{array}$ & $\begin{array}{l}\text { Fewer tumors after } \\
\text { transplant. }\end{array}$ & {$[60]$} \\
\hline
\end{tabular}

Microbe availability can influence physiological changes in cells. For instance, the presence of particular microbes can lead to inflammation via IL-10 generation. Recent studies on other types of cancer and microbial metabolomics have led to the discovery o new biomarkers. In colitis cases, there is a 10-fold increase in the incidence ofcolorectal cancer and inflammation occurs due to the presence of members of the Enterobacteriaceae family, such as Enterococcus faecalis and Escherichia coli. These strains are upregulated $>100$-fold in colon cancer [61-63].Polyketide synthases ( $p k s$ ) found in E.coli, synthesizes the genotoxiccolibactin. However, this gene is not found in E. faecalis, which makes E. faecalis less virulent in comparison to E. coli. The metabolic product of E. coli, pks induces DNA damage [63]. The risk factor may even be increased due to the presence of food, which affects the microbiota. The heterocyclic amines present in red meatare fermented by gut microbiota to yield hydrogen sulfide and electrophilic free radicals, which cause DNA damage and subsequent mutation via faulty DNA repair [64]. In cases of obesity, microbiota is found to be enriched by diverse microbes. Therefore, the chances of cancer occurrence are 
higher in obese persons [65]. Individuals on a high fat diet are rich in group IX Firmicutes bacteria, such as Clostridium, which convert bile acids into secondary compounds, often deoxycholic acid (DCA). DCA generates free radicals, so it is a potent carcinogen and has been reported to cause liver and colorectal cancers [66]. More information related to microbes and mechanisms is given in Table 4 [67-94].

Table 4. Microbes and carcinogenic mechanisms.

\begin{tabular}{|c|c|c|c|}
\hline Type of Cancer & $\begin{array}{l}\text { Role of Microbes/Mechanism of } \\
\text { Carcinogenesis }\end{array}$ & Evidence/Proof & References \\
\hline $\begin{array}{c}\text { Gastric } \\
\text { lymphoma of the gastric } \\
\text { MALT, } \\
\text { IPSID, } \\
\text { MALT lymphoma of the skin, } \\
\text { adnexal ocular lymphoma }\end{array}$ & $\begin{array}{l}\text { Chronic infection with Helicobacter pylori } \\
\text { Patients with chronic infection with } \\
\text { H. pylori, Campylobacter jejuni, } \\
\text { Borreliaburgdorferi, or Chlamydia psittaci }\end{array}$ & $\begin{array}{l}\text { Epidemiology support } \\
\text { Reduction by H. pylori } \\
\text { Eradication } \\
\text { Antibiotic treatment }\end{array}$ & [63-73] \\
\hline Esophageal & $\begin{array}{l}\text { Decreased risk in patients who have } \\
\text { H. pylori infection }\end{array}$ & Epidemiology support & {$[70,74]$} \\
\hline Gallbladder & $\begin{array}{l}\text { Chronic infection with Salmonella enteric } \\
\text { subsp. enterica serovar Typhi }\end{array}$ & Epidemiology support & {$[75,76]$} \\
\hline Breast & $\begin{array}{l}\text { Increased } \mathrm{T} \text { regulatory cell-mediated } \\
\text { inflammation }\end{array}$ & $\begin{array}{l}\text { Cancer promoted in } \\
\text { ApcMin/ + mice infected with } \\
\text { Helicobacter hepaticus }\end{array}$ & [77] \\
\hline Liver & Chronic hepatitis & $\begin{array}{l}\text { Cancer facilitated in mice } \\
\text { infected with } H \text {. hepaticus }\end{array}$ & [78] \\
\hline Colorectal & TNF-mediated and NO-mediated & $\begin{array}{l}\text { Cancer supported in Rag } 2^{-/-} \\
\text {mice infected with } H \text {. hepaticus }\end{array}$ & [79] \\
\hline Colorectal & $\begin{array}{ll}\text { - } & \text { Barrier failure } \\
\text { - } & \text { Dysbiosis } \\
\text { - } & \text { Bacterial genotoxicity } \\
& \text { Chronic inflammation }\end{array}$ & $\begin{array}{l}\text { Cancer reduction by } \\
\text { antibiotics and in germ-free } \\
\text { mice; transmission of } \\
\text { dysbiotic microbiota triggers } \\
\text { cancer development }\end{array}$ & [80-84] \\
\hline Liver & $\begin{array}{l}\text { Increased liver sensitivity to } \\
\text { MAMP-activating TLRs } \\
\text { Increased sensitivity to the secondary } \\
\text { bile acid (DCA) }\end{array}$ & $\begin{array}{l}\text { Cancer reduction by treatment } \\
\text { with antibiotics and in } \\
\text { germ-free mice } \\
\text { Cancer increased by treatment } \\
\text { with LPS and DCA }\end{array}$ & {$[85,86]$} \\
\hline Lung & Increased bacterial infection in COPD & $\begin{array}{l}\text { Decreased cancer in germ-free } \\
\text { animals } \\
\text { The promotion of cancer by } \\
\text { LPS and infections }\end{array}$ & {$[87-91]$} \\
\hline Pancreatic & LPS-TLR4-mediated increase & $\begin{array}{l}\text { LPS treatment increases } \\
\text { cancer development }\end{array}$ & [92-94] \\
\hline
\end{tabular}

\subsection{Colon Cancer}

Colon cancer is the third deadliest cancer globally. The colon is the main area where microbesrecides, especially bacteria (phylum Firmicutes). These bacteria remain inside the colon and utilize the food materials found within [95]. In response to food materials and their post metabolism, they secrete several byproducts into the bloodstream. These byproducts can increase or decrease the levels and expression of certain cancer-causing molecules and genes. Microbes promote intestinal homeostasis and anti-oncogenic responses but may elicit oncogenic responses through chronic dysregulated inflammation and genotoxic effects. Certain microbes that can increase the risk of colorectal cancer have 
recently been identified $[95,96]$. The promotion of a healthy vs. cancerous colon depends on the basic composition of the gut microbiota and the dynamic equilibrium within the microbial community $[97,98]$. Recently, disturbances in the normal population of microbiota have been reported to be the main cause of colorectal cancer (CRC), as shown by dysbiosis [99,100]. F. nucleatum and E. coli have been reported in most CRC patients [101]. Recent studies on mice have concluded that $F$. nucleatum directly participates in enhancement of tumor growth. Hence, F. nucleatum can work as a major prognostic biomarker in colon cancer studies [102] (Figure 2). $\mathrm{CD}^{+} \mathrm{T}$ cell count decreases as F. nucleatum increases. Proteins from F. nucleatum bind with TIGIT, E-cadherin, Fap2, and FadA and providing very important information for the design of drugs against these targets. E. coli is more tumorigenic with polyketide synthase than without, indicating that intestinal inflammation helps in targeting the cancer-inducing activity of the microbiota [103] (Figure 2). Butyrate, an important byproduct metabolite of SCFA (short chain fatty acid), is derived from E. coli and is a potential major genotoxic and epigenetic modulating molecule. It has deleterious effects on local gut flora. It is clear that balance of microbes present in the gut determines initiation and suppression of cancer. It has been shown that, compared with control mice, germ-free mice that lack microbes are more prone to tumor development after treatment with the carcinogens dextran sulfate sodium (DSS) and azoxymethane (AOM) [104].The mechanisms behind this support the repair of epithelial and barrier functions that allow for the resolution of inflammation at the time of epithelium damage.The down regulation of inflammatory pathways likely induces the prevention of dysbiosis, tumorigenesis and the increased apoptosis of tumor cells, while the up regulation of cytokines such as IL-18 likely induces antitumor responses and tissue repair.

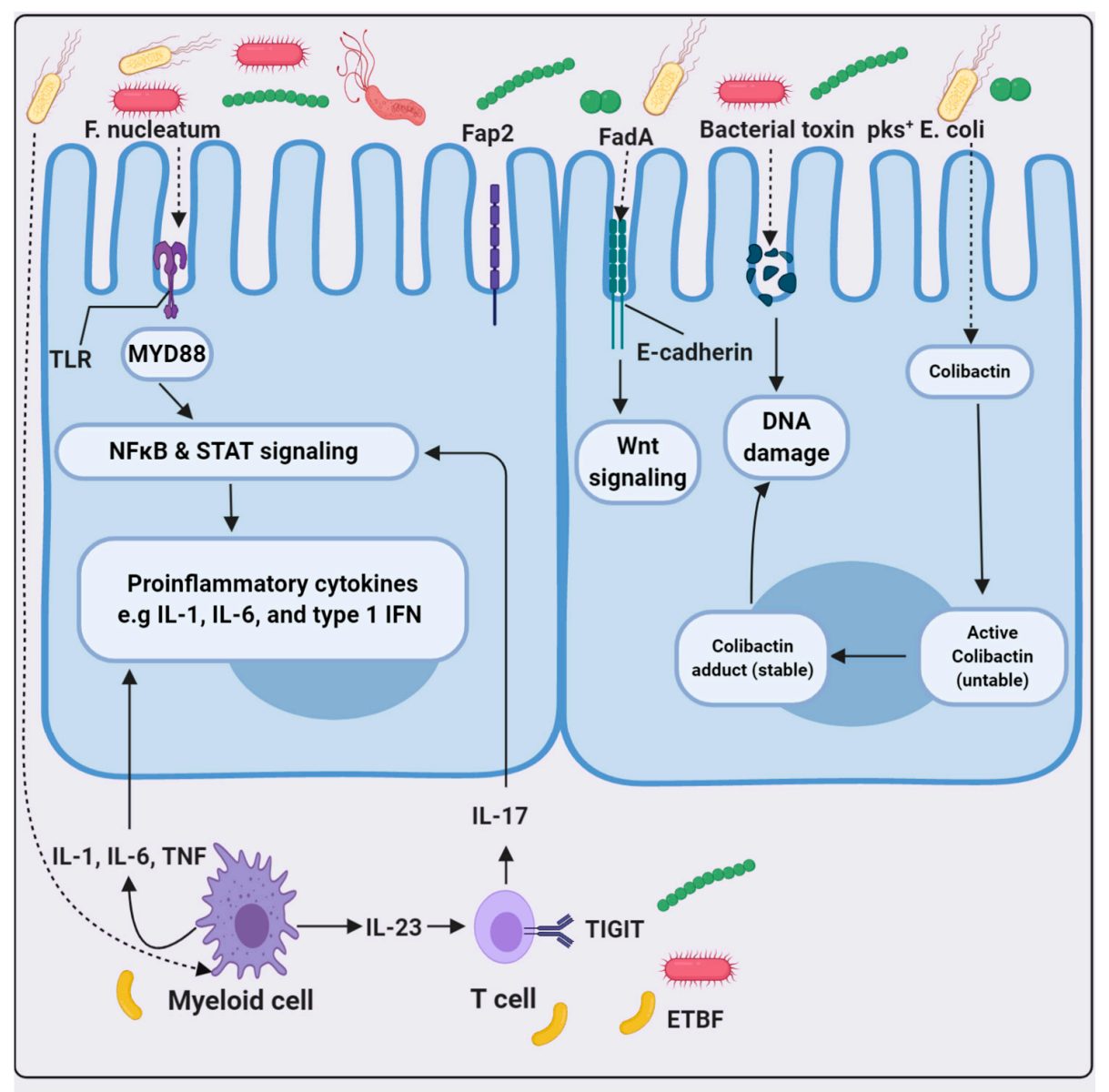

Figure 2. Three major examples of the possible mechanism through which microorganisms cause colorectal cancer. F. nucleatum, ETBF, and polyketide synthase-expressing $\left(\mathrm{pks}^{+}\right)$E. colihave a causative role in mediating colorectal cancer. 


\subsection{Breast Cancer}

Breast cancer is reported in one of eight women in the United States. It is the most prevalent cancer in women after lung and colon cancer. Breast cancer is regarded as a familial (genetically) $\mathrm{HR}^{+}$-related mutation and is linked with changes related to estrogen. However, in recent studies, it has been reported that microbes (especially in the gut) also play a role in progression in breast cancer. Bile acid production is controlled by microbes found in the gut. Dihydroxy acid (DHA), secreted by the action of microbes, especially E. coli, has a direct influence on the estrogen metabolome [105]. Excess estrogen can deregulate various regulated pathways and cause overexpression of factors that cause breast cancer. It is now known that microbes present in the gut, mouth, breast, and breast milk influence estrogen metabolism, inflammation, and epigenetic alterations [106]. Some bacteria and their secreted metabolites can affect different types of signaling pathways, such as E-cadherin/ $\beta$-catenin [107], which functions as a major promoter of apoptosis and double-strand breaks in DNA [59], alters cell differentiation [108], and is linked with innate immunity and some toll-like receptors (TLRs), which activates inflammatory signaling pathways that ultimately help in maintaining body homeostasis [109-111]. In the case of Breast Cancer (BC), Proteobacteria and Firmicutes species have been found in greater abundance. In separate samples, these two groups of bacteria serve as the key causative agent of breast cancer. In patients with advance breast cancer, $16 \mathrm{~S}$ rRNA analysis demonstrated a very high relative abundance of three groups of bacteria, namely Staphylococcus, Bacillus, and Enterobacteriaceae spp. Moreover, Escherichia coli (Enterobacteriaceae) and Staphylococcus epidermidis are known to be responsible for double-stranded DNA breaks [112]. A study on Irish and Canadian women with breast cancer found they were more likely to have elevated levels of bacteria belong to the Enterobacteriaceae, Staphylococcus, and Bacillus compared with women who do not have breast cancer [113]. Enterobacteriaceae (8.3\%), Prevotella (5.0\%), Bacillus (11.4\%), Acinetobacter (10.0\%), Pseudomonas (6.5\%), Propionibacterium (5.8\%), Comamonadaceae (5.7\%), Gammaproteo bacteria (5.0\%) and Staphylococcus (6.5\%) were all represented as indicated in Canadian women with breast cancer. The most abundant represented taxon was Pseudomonas (5.3\%), Enterobacteriaceae (30.8\%), Propionibacterium (10.1\%), Listeriawelshimeri $(12.1 \%)$, and Staphylococcus $(12.7 \%)$ were present in samples taken from Irish women with BC. The composition of bacterial and viral populations associated with breast cancer differs according to the examined breast position, as revealed by 16S RNA sample analysis, as explained by Zahra Eslami-S et al., 2020 (Figure 3). More abundant Methylobacterium, Staphylococcusand Actinomyceteswere found in urine samples of breast cancer patients. Lactobacillus acidophilus, a well-known probiotic present in kimchi and yogurt, can easily enter the mammary gland of the breast and displays a variety of anticancer properties [114]. Women can face a high incidence of protective antioxidant effects if they consume fermented milk products. It is very widely stated that the abundance of Lactococcus and Lactobacillus spp. in healthy breast tissues, relative to cancerous breast cancer tissues, possibly plays a role in the cure and prevention of breast cancer. Some studies indicate that Lactobacillus is often involved in controlling the immune system and reducing the amount of C-reactive protein and IL-6 that function as pro-inflammatory factors during inflammatory reactions [115]. In benign and malignant breast tissue samples, there is an enormous difference in the persisting microbiome composition (Figure 3). A review of taxonomic studies reveals that in the case of benign and invasive breast cancer, the overall microbiota of breast tissue, were very similar and dominated by the bacterial phyla Firmicutes and Bacteroidetes, as expected. The malignancy associated with enrichment could be determined by the assessment of differential taxa of bacterial species between these two classes. The lower abundance taxa are likely to include Hydrogenophaga, Lactobacillus, Atopobium, Gluconacetobacter and Fusobacterium genera [116]. In the case of breast cancer, the carcinogenic effect of 10 well-known infectious pathogens has been identified. A greater understanding of the effects and function of these microbial agents in breast cancer would broaden our ability to prevent development of tumor and potentially lead to future diagnosis tools and treatments. In the late nineties, gastric cancer and breast 
cancer were linked to infections with Helicobacter pylori and Salmonella typhi these two well-known bacterium also participates in gallbladder cancer. More surprisingly, in the case of bladder cancer, breast cancer, colon cancer, and melanoma, $S$. typhus also serves as a promising carrier of therapeutic agents [116]. It is important to study the interactions between microenvironments and microbiomes linked to different organs within the human body and understanding their breast cancer development [117].

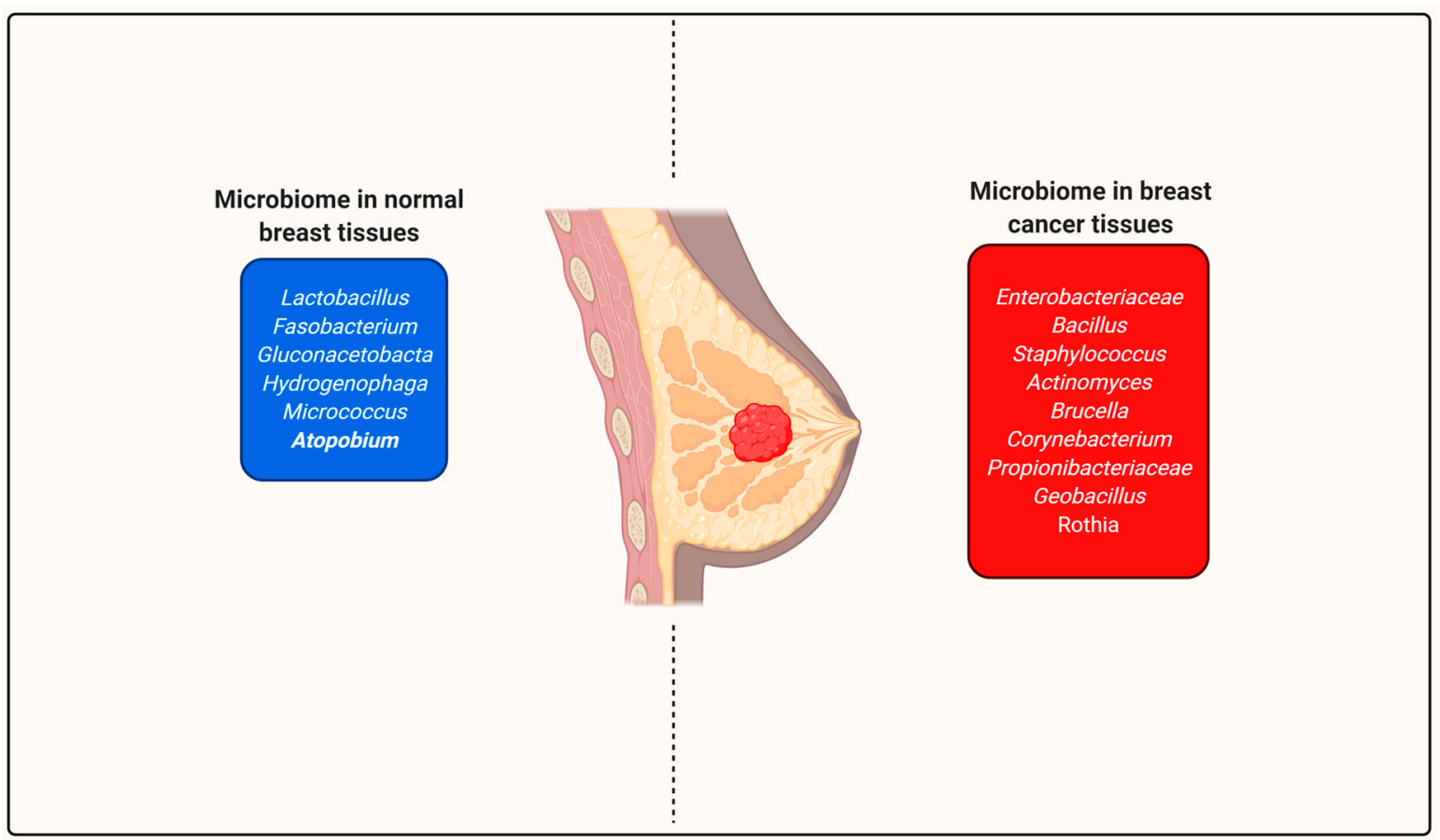

Figure 3. Microbiome changes associated with breast cancer and normal breast tissues; the microbiota mixtures in malignant and benign breast tissue specimens are substantially different and diversity of microbiota is likely to result in carcinogenesis.

\subsection{Oral Cancer}

High throughput16S rRNA sequencing of mouth cavity of healthy individuals reveals the presence of five major phyla namely Fusobacteria, Bacteroidetes, Actinobacteria, Proteobacteria, and Firmicutes. Major genera Veillonella, Streptococcus, Prevotella, Haemophilus, Neisseria and Leptotrichia as found when assaying various parts of the mouth [118]. According to recent reports, the principal pathogen present in periodontal Porphyromonas gingivalis has been identified as a major biomarker for oral digestive cancer and related death and it also expand to colorectal and pancreatic cancer [119]. Recent studies suggest correlations between both oral fungal and viral microbes in the development of oral cancer. A prime example of this is human papillomavirus 16 (HPV-16), a major causative agent of several carcinomas related to oropharyngeal squamous cells [120,121]. Early studies through culture-dependent assays show that squamous cells of oral carcinomas have enormously increased abundance of both aerobic and anaerobic types of bacteria. The anaerobes belong to Clostridium, Veillonella, Fusobacterium, Porphyromonas, Prevotella and Actinomyces, while aerobes belong to Streptococcus, Haemophilus and Enterobacteriaceae. In addition, about 30\% of oral cancers have been shown to be due to Candida albicans [122].

\subsection{Liver Cancer}

The third leading cause of cancer mortality belongs to hepatocellular carcinoma (HCC). Bacterial dysbiosis, leaky gut, microbe-associated bacteria and metabolite molecular patterns work as key pathways that impel cancer-induction, genotoxicity, liver inflammation, and fibrosis [123,124]. Therefore, it is difficult to both manage and diagnose liver cancer. 
The microbiome present inside the human gut may answersome present unexpected questions. Researchers have developed a new method for microbiome-based identification of liver fibrosis and cirrhosis easily, economically with more than $90 \%$ accuracy $[125,126]$. Non-alcoholic fatty liver disease (NAFLD) is the world's leading cause of chronic liver disease and can lead to cirrhosis and liver fibrosis and, eventually the development of cancer $[127,128]$. However, advanced diagnostic methods for liver cirrhosis and fibrosis diagnosis are still lacking. In certain regions of the liver, biopsies function as an invasive tool and can cause damage. Magnetic Resonance Imaging (MRIs) are costly and are less commonly available in rural areas [129]. One study group studied the microbiome as a method to administer new tests to classify patients as vulnerable to liver cancer in order to bypass potential development. This procedure is based on 19 species of bacteria that have been described and are often present in a patient's stool samples. Microbiome signature associated with liver cirrhosis was identified using microbiome genetic profiling and metabolites analysis fromstool samples with $94 \%$ accuracy [130]. In future, this can potentially assist clinicians in assessing the stage and level of the disease and eventually promote the development care strategies. The basic patterns we observed reflect the complexity of the microbiome and the way in which liver cancer disease affects gut health [131]. The study suggested investigating the causal relation between the liver and microbiome disease. They are also optimistic that this method may be used to characterize other diseases, such as inflammatory bowel disease and Alzheimer's disease, in which a dysregulated microbiome has been associated diseases $[132,133]$. Compared with minimal fibrosis and stable controls, the microbiome composition is very distinct in liver cancer patients with advanced fibrosis. The effect of the intestinal microbiome on the characteristics of chronic liver disease, its association with non-alcoholic liver fatty liver disease (NAFLD), and primary sclerosing cholangitis has recently been demonstrated [134].

Since advanced fibrosis is a significant predictor of liver disease-related mortality and morbidity, researchers are simply trying to find and classify biomarkers of gut microbiome fibrosis. Scientists have identified that NAFLD, hepatitis B, hepatitis C, and alcoholic liver disease are primarily caused by unique patterns in the gut microbiome of patients with cirrhosis [135]. Lower concentrations of Bacteroides and higher levels of Prevotella bacteria have been characterized by those with advanced fibrosis those of the species Prevotellacopri, which acts as a good indicator of advanced liver fibrosis and chronic liver disease. The components and relative abundance of the gut microbiome differ significantly between individuals. The number of distinct bacterial phyla, Fusobacteria, Firmicutes, Proteobacteria, Actinobacteria, and Bacteroidetes typically prevail in liver cancer [136]. For example, human papillomavirus infection, $H$. pylori and hepatitis $C$ viruses are major risk factors for their respective development of cervical, stomach, and liver cancer [137]. Salmonella enteric, which causes damage to DNA, produces secondary bile acids that support inflammation and contribute to tumor development [138]. Escherichia coli cause DNA damage to hydrogen sulfide production, which can decrease mucous production and contribute to intestinal barrier breakdown [139]. The development of reactive oxygen species, lipopolysaccharides, and reactive nitrogen species is indicated by Fusobacterium nucleatum, which shows leaky junctions and inflammation [140]. This is likely to be due to the complex interplay of a variety of other variables, such as human biology, exposure to contaminants or other pollutants in the atmosphere, and lifestyle (diet, drinking and smoking) [141]. Among these variables, the impact of dieting on the gut microbiome is best understood and well founded. The key cause of the development of potentially carcinogenic compounds has been found to be obesity and calorie-rich diets high in protein and fat. N-nitroso derivatives, secondary bile acids, and branched-chain fatty acids are primarily found in these derivatives. Decreased cancer risk has been associated with diets that are high in fiber and plant compounds such as glucosinolates (sulfur-containing compounds), polyphenols, and flavonoids [142]. Bifidobacterium longum is a gut commensal short-chain fatty acid (SCFA)-producing bacterium that helps in preventing cancer. SCFAs specifically involve butyrate, propionate, acetate [143], and complex carbohydrate and dietary fiber bacterial 
fermentation throughout the gut. These compounds can mainly assist in maintaining close bowel junctions and nourishing colon cells. Other beneficial bacteria include Lactobacillus acidophilus which helps preserve DNA [144], and Saccharomyces boulardii, which can minimize inflammation by preventing DNA damage and tumor growth [145-147].

\section{Microbiome Impact on Immunotherapy}

Under normal circumstance, the immune system work to defend the host against infectious diseases, autoimmunity, and allergy through the action of a series of co-stimulatory and co-inhibitory receptors and their ligands, commonly called immune checkpoints [148]. According to recent evidence, tumors use many of these pathways to evade antitumor immune responses and eventually progress, disseminate, and metastasize. Immune checkpoints are molecules that need to be stimulated or inactivated by specific immune cells to initiate a specific form of immune response to fight disease or inflammation [149]. Many cancer cells often avoid being targeted and destroyed by the immune system via these checkpoints. As shown by monoclonal antibodies (mAbs) inhibiting cytotoxic T-lymphocyte antigen-4 (CTLA-4), and programmed cell death protein1/programmed cell death ligand 1 (PD-1/PD-L1) [150,151], immune checkpoint inhibitors (ICIs), referred to as novel immunotherapeutic agents, have shown very promising clinical implications for advanced hematologic malignancies. It is well-established that microbiome changes to the tumor microenvironment (TME) result in the advancement of immunomodulatory effects [152]. However, these implications pose new and wide-range concerns, such as whether there is a correlation between cancer immunotherapy and the gut microbiome. Here, we concentrate on recent data on developments in cancer immunotherapy and intestinal microbiome to address these issues. Drugs that are widely used to target these targets are providing a positive road to cancer treatment. These medications are well-known as checkpoint inhibitors [150]. Cancer immunotherapy has become a very exciting and evolving field of modern oncology for treating cancer patients. To generate an antitumor effect, the immune system uses these control points and their inhibitors. The role of microbiota in managing the immune system and inflammatory reactions has been demonstrated using germ-free mice. Inappropriate inflammatory reactions against commensal microbiota such as E. coli and E.hirae are prevented by interleukin-10 (IL-10) [153]. E. faecalis IL-10 knockout mice have shown a form of colitis phenotype. However, if grown in a germ-free environment, the colitis activity of knockout mice can be suppressed [154]. Growth factor- $\beta 1$ knockout mice also carry these forms of cancer in a germ-free background [155]. To establish the role of microbes in certain types of humandiseases through the provision of specific microbes, the use of germ-free mice is important. Based on previous research, multiple findings indicate that intestinal microbes influence antitumor activity in a variety of ways. Microbes or their metabolic products, through their association with antigen-presenting cells (APCs) or toll-like receptors (TLRS) help to alter the immune response [156]. In reaction to chemotherapy, preclinical models have been used to demonstrate the impact of microbiota on the gut. Cyclophosphamide and oxaliplatin have been shown to modulate antitumor activity by involving local microbes and their metabolites (maturation of T helper 17-TH 17 is achieved) for chemotherapy purposes in cancer treatment [157].

Specific gut microbiota affects the immune response to different treatments during the immunotherapy, surgery, and radiation [158]. Further research is needed to evaluate the increase or decrease in the number of microbes during different treatments strategies provided for cancer treatment. Conclusions on the impact of microbes in relation to cancer therapy including the studied models, are detailed in Table 5 [159]. Fecal microbiota transplantation (FMT) is now being investigated with different cancer types and cell models and the findings with reference to immunotherapy are also shown in the referred Table 6 [160]. The relation between gut microbiome composition and the efficacy of carcinoma therapy is shown in Table 7 . This table presents the key findings of preclinical and clinical studies showing the link between gut bacteria and the results of various treatments for different types of cancer and treatment regimes. 
Table 5. Unique clinical trials carried out in response to cancer therapy worldwide to improve the gut microbiome [159].

\begin{tabular}{|c|c|c|c|c|c|}
\hline $\begin{array}{l}\text { Global NCT } \\
\text { Number }\end{array}$ & $\begin{array}{c}\text { Type of } \\
\text { Malignancy }\end{array}$ & Aim & Intervention & $\begin{array}{c}\text { Results/Outcome } \\
\text { Measures }\end{array}$ & Place \\
\hline 03290651 & Breast cancer & $\begin{array}{c}\text { To determine if } \\
\text { oral antibiotics can } \\
\text { change the breast } \\
\text { flora }\end{array}$ & $\begin{array}{l}\text { Probiotics Natural } \\
\text { Health } \\
\text { Product-RepHresh } \\
\text { Pro-B }\end{array}$ & $\begin{array}{l}\text { Change in breast } \\
\text { microbiota, } \\
\text { inflammatory } \\
\text { markers }\end{array}$ & Canada \\
\hline 03341143 & Melanoma & $\begin{array}{l}\text { To establish } \\
\text { concurrent use of } \\
\text { FMT and } \\
\text { pembrolizumab in } \\
\text { patients with } \\
\text { PD-1-resistant } \\
\text { melanoma }\end{array}$ & $\begin{array}{l}\text { FMT (donor } \\
\text { responder to PD-1 } \\
\text { therapy) with } \\
\text { pembrolizumab }\end{array}$ & $\begin{array}{l}\text { ORR, change in } \mathrm{T} \\
\text { cell composition } \\
\text { and function, } \\
\text { change in innate } \\
\text { and adaptive } \\
\text { immune subsets }\end{array}$ & USA \\
\hline 00936572 & Colorectal cancer & $\begin{array}{l}\text { To investigate the } \\
\text { effect of probiotics } \\
\text { on gut microflora } \\
\text { and the immune } \\
\text { and inflammatory } \\
\text { response }\end{array}$ & $\begin{array}{l}\text { Probiotics } \\
\text { (La1, BB536) }\end{array}$ & $\begin{array}{l}\text { To perform } \\
\text { morphological and } \\
\text { microbiological } \\
\text { evaluation of the } \\
\text { colonic microflora, } \\
\text { GI function }\end{array}$ & Italy \\
\hline 03072641 & Colorectal cancer & $\begin{array}{l}\text { To reactivate the } \\
\text { tumor-suppressor } \\
\text { genes using } \\
\text { probiotics }\end{array}$ & $\begin{array}{l}\text { ProBionClinica (Bi- } \\
\text { fidobacteriumlactis, } \\
\text { L. acidophilus) }\end{array}$ & $\begin{array}{l}\text { Changes in } \\
\text { microbiota } \\
\text { composition and } \\
\text { DNA methylation }\end{array}$ & Sweden \\
\hline 01609660 & Colorectal cancer & $\begin{array}{l}\text { To assess the } \\
\text { impact of } \\
\text { probiotics on } \\
\text { patients } \\
\text { undergoing } \\
\text { colorectal } \\
\text { resections }\end{array}$ & $\begin{array}{c}\text { Saccharomyces } \\
\text { boulardii }\end{array}$ & $\begin{array}{c}\text { To measure } \\
\text { mucosal cytokines, } \\
\text { SCFA } \\
\text { postoperative } \\
\text { complications, and } \\
\text { hospital LOS }\end{array}$ & Brazil \\
\hline 00197873 & Colorectal cancer & $\begin{array}{l}\text { To prevent } \\
\text { chemotherapy- } \\
\text { induced } \\
\text { diarrhea }\end{array}$ & $\begin{array}{c}\text { L. rhamnosus } \\
\text { supplementation }\end{array}$ & $\begin{array}{c}\text { Effect on } \\
\text { treatment-related } \\
\text { toxicity other than } \\
\text { diarrhea }\end{array}$ & Finland \\
\hline 02269150 & $\begin{array}{l}\text { Malignancies } \\
\text { requiring } \\
\text { allo-HSCT }\end{array}$ & $\begin{array}{l}\text { To assess the utility } \\
\text { of FMT in } \\
\text { prevention of CDI } \\
\text { in patients who } \\
\text { underwent } \\
\text { allo-HSCT }\end{array}$ & Auto-FMT & CDI & USA \\
\hline 02928523 & $\begin{array}{l}\text { Acute myeloid } \\
\text { leukemia }\end{array}$ & $\begin{array}{l}\text { To use FMT to } \\
\text { prevent } \\
\text { complications } \\
\text { associated with } \\
\text { dysbiosis in } \\
\text { patients } \\
\text { undergoing } \\
\text { intensive treatment }\end{array}$ & Auto-FMT & $\begin{array}{c}\text { Dysbiosis } \\
\text { correction, } \\
\text { eradication of } \\
\text { multidrug resistant } \\
\text { bacteria, definition } \\
\text { of dysbiosis, } \\
\text { biosignature }\end{array}$ & France \\
\hline 03552458 & $\begin{array}{l}\text { Head-and-neck } \\
\text { cancer }\end{array}$ & $\begin{array}{l}\text { To assess the role } \\
\text { of probiotics in } \\
\text { preventing oral } \\
\text { mucositis }\end{array}$ & $\begin{array}{l}\text { Lactobacillus reuteri } \\
\text { Oral Solution } \\
\text { (BioGaia) }\end{array}$ & $\begin{array}{c}\text { Oral mucositis } \\
\text { severity, oral } \\
\text { bacterial genetics, } \\
\text { and transcriptional } \\
\text { analysis }\end{array}$ & Singapore \\
\hline
\end{tabular}


Table 6. Manipulation ofthe gut microbiome to alleviate responses to cancer immunotherapy [160].

\begin{tabular}{|c|c|c|c|}
\hline Accession or Trial Number & Intervention & Targeted Patient Population & Finding(s) \\
\hline NCT03072641 & $\begin{array}{c}\text { Irregular probiotics } \\
\text { supplements } \\
\text { (ProBionClinicaB. lactis BI-04, } \\
\text { L. acidophilus Inulin+ } \\
\text { NCFM) Intake }\end{array}$ & CRC patients ages $18^{+}$ & $\begin{array}{c}\text { Primary: change in fecal and } \\
\text { tumor microbiota. Secondary: } \\
\text { Changes in epigenetics } \\
\text { patterns of tumor tissue. }\end{array}$ \\
\hline NCT01895530 & $\begin{array}{l}\text { Randomized probiotic } \\
\text { (S. Boulardii) administration }\end{array}$ & $\begin{array}{c}\text { CRC patients ages } 18^{+} \\
\text {undergoing elective } \\
\text { CRC resection }\end{array}$ & $\begin{array}{l}\text { Primary: cytokine expression } \\
\text { in colonic mucosa (via qPCR). } \\
\text { Secondary: post-operative } \\
\text { complications. }\end{array}$ \\
\hline NCT03358511 & $\begin{array}{l}\text { Single-arm probiotics (Primal } \\
\text { Defense Ultra multi-strain } \\
\text { probiotics formula) }\end{array}$ & $\begin{array}{l}\text { Post-menopausal breast } \\
\text { cancer patients (stages I-III) }\end{array}$ & $\begin{array}{l}\text { Primary: change in mean } \\
\text { number of } \mathrm{CD}^{+} \text {cells. }\end{array}$ \\
\hline NCT03353402 & $\begin{array}{l}\text { Single-arm FMT (colonoscopy } \\
\text { or gastroscopy) from patient } \\
\text { donors who responded to } \\
\text { immunotherapy }\end{array}$ & $\begin{array}{l}\text { Metastatic melanoma patients } \\
\text { ages } 18^{+} \text {who previously } \\
\text { failed standard therapies }\end{array}$ & $\begin{array}{l}\text { Primary: safety (AEs } \\
\text { associated with FMT), } \\
\text { engraftment of FMT. } \\
\text { Secondary: changes in } \\
\text { immune cell populations and } \\
\text { activity, objective } \\
\text { response rate. }\end{array}$ \\
\hline NCT02928523 & $\begin{array}{l}\text { Single-arm autologous FMT } \\
\text { (frozen inoculum) }\end{array}$ & $\begin{array}{c}\text { Acute myeloid leukemia } \\
\text { patients ages } 18-65 \text { treated } \\
\text { with intensive chemotherapy } \\
\text { and antibiotics }\end{array}$ & $\begin{array}{c}\text { Primary: diversity of the gut } \\
\text { microbiome, } \\
\text { multi-drug-resistant } \\
\text { bacteria eradication. } \\
\text { Secondary: signature } \\
\text { of dysbiosis. } \\
\text { of the gut microbiome. }\end{array}$ \\
\hline NCT02079662 & $\begin{array}{l}\text { Randomized intensive } \\
\text { lifestyle change (diet, exercise, } \\
\text { psychosocial) }\end{array}$ & $\begin{array}{l}\text { Stages II and III breast cancer } \\
\text { patients treated at MDACC } \\
\text { ages } 18^{+}\end{array}$ & $\begin{array}{l}\text { Primary: disease-free survival } \\
\text { (DFS). } \\
\text { Secondary: change in fecal } \\
\text { and oral microbiome (via } \\
\text { 16S profiling). }\end{array}$ \\
\hline NCT02843425 & $\begin{array}{l}\text { Addition of } \frac{1}{2} \text { cup beans per } \\
\text { day to regular diet in a } \\
\text { crossover design }\end{array}$ & $\begin{array}{l}\text { All cancer patients treated at } \\
\text { MDACC }\end{array}$ & $\begin{array}{l}\text { Primary: change in fecal } \\
\text { microbiome profile. }\end{array}$ \\
\hline
\end{tabular}

Table 7. Link between the compositions of the gut microbiome and the effectiveness of carcinoma therapy.

\begin{tabular}{llll}
\hline \multicolumn{1}{c}{ Main Outcome } & Data Source & \multicolumn{1}{c}{ Carcinoma/Treatment } & References \\
\hline $\begin{array}{l}\text { Immunological therapy } \\
\begin{array}{l}\text { Commensal type of microbiota } \\
\text { needed for standard response } \\
\text { to treatment }\end{array}\end{array}$ & Rodent-mouse & $\begin{array}{l}\text { Several models of } \\
\text { carcinoma/anti-IL-10R antibody + } \\
\text { CpG oligonucleotide and oxaliplatin } \\
\text { (platinum-chemotherapy) }\end{array}$ & [161] \\
\hline
\end{tabular}

Irradiation of whole body with disruption of the intestine barrier and enhanced response of T-lymphocyte cell-mediated treatment via 
Table 7. Cont.

\begin{tabular}{|c|c|c|c|}
\hline Main Outcome & Data Source & Carcinoma/Treatment & References \\
\hline $\begin{array}{l}\text { Firmicutes and Faecalibacterium } \\
\text { presence in baseline samples of stool } \\
\text { liked with ICB response; abundance } \\
\text { of Bacteroides linked with low } \\
\text { ICB response }\end{array}$ & Human & $\begin{array}{l}\text { Melanoma (Metastatic } \\
\text { stage)/CTLA-4 inhibitor }\end{array}$ & [163] \\
\hline $\begin{array}{l}\text { Abundance of Blautia linked with } \\
\text { overall increased survival rate and } \\
\text { decreased GVHD risk }\end{array}$ & Human & Hematologic cancers / Allo-HSCT & [164] \\
\hline $\begin{array}{l}\text { Bacteroides abundance was associated } \\
\text { with resistance to ICB-induced colitis }\end{array}$ & Human & $\begin{array}{l}\text { Melanoma (Metastatic } \\
\text { stage)/CTLA-4 inhibitor }\end{array}$ & [165] \\
\hline $\begin{array}{l}\text { Abundance of Bifidobacterium linked } \\
\text { with enhanced automatic immunity } \\
\text { against tumor and ICB response }\end{array}$ & Rodent-mouse & Melanoma/Anti-PD-L1 inhibitor & [166] \\
\hline $\begin{array}{l}\text { Abundance of Bacteroides liked with } \\
\text { ICB response }\end{array}$ & Rodent-human & $\begin{array}{l}\text { Melanoma (Metastatic } \\
\text { stage)/CTLA-4 inhibitor }\end{array}$ & [167] \\
\hline $\begin{array}{l}\text { Abundance of Eubacterium limosum } \\
\text { linked with reduced chances of } \\
\text { progression of disease or relapse }\end{array}$ & Rodent-human & Blood cancer / Allo-HSCT & [168] \\
\hline $\begin{array}{l}\text { Faecalibacterium prausnitzii, Bacteroides } \\
\text { caccae, Holdemaniafiliformis, Bacteroides } \\
\text { thetaiotaomicron, and } \\
\text { Doreaformicigenerans linked with } \\
\text { ICB response }\end{array}$ & Human & $\begin{array}{l}\text { Melanoma (Metastatic } \\
\text { stage)/CTLA-4 inhibitor; } \\
\text { PD-1 inhibitor }\end{array}$ & [169] \\
\hline $\begin{array}{l}\text { Large number of bacteria in the } \\
\text { sample of baseline stool found to be } \\
\text { enriched differentially between } \\
\text { strong ICB response patients vs. poor } \\
\text { ICB response patients }\end{array}$ & Human & $\begin{array}{l}\text { Mouse-melanoma } \\
\text { (Metastatic)/PD-1 inhibitor }\end{array}$ & [170] \\
\hline $\begin{array}{l}\text { Clostridiales, high microbiome } \\
\text { richness and abundance of } \\
\text { Faecalibacterium, Ruminococcaceae } \\
\text { with ICB response in baseline } \\
\text { stool samples }\end{array}$ & Mouse; Human & $\begin{array}{l}\text { Melanoma (Metastatic } \\
\text { stage)/PD-1 inhibitor }\end{array}$ & [171] \\
\hline $\begin{array}{l}\text { Abundance of } A . \text { muciniphila in the } \\
\text { samples of baseline stool found to be } \\
\text { linked with ICB response }\end{array}$ & Mouse; Human & $\begin{array}{l}\text { lung carcinoma of non-small cell; } \\
\text { Renal cancer/PD-1 inhibitor }\end{array}$ & [172] \\
\hline $\begin{array}{l}\text { Chemotherapy with } \\
\text { immunostimulatory properties } \\
\text { Existence of intratumoral } \\
\text { Gammaproteobacteria linked with } \\
\text { gemcitabine chemotherapy resistance }\end{array}$ & Mouse; Human & $\begin{array}{l}\text { Adenocarcinoma (Ductal } \\
\text { Pancreatic)/Gemcitabine } \\
\text { immunomodulatory } \\
\text { chemotherapy treatment }\end{array}$ & [173] \\
\hline $\begin{array}{l}\text { Abundance of Akkermansia } \\
\text { muciniphila in the samples of baseline } \\
\text { stool found to be liked with } \\
\text { ICB response }\end{array}$ & Rodent-Mouse & $\begin{array}{l}\text { Several models of } \\
\text { carcinoma/immunomodulatory } \\
\text { chemotherapy Cyclophosphamide }\end{array}$ & [174] \\
\hline
\end{tabular}

\subsection{Microbiome Implications in CTLA-4 Based Immunotherapy}

CTLA-4 is a type of protein found in specific T cells that function as a type of "off and on switch" that introduces vigilance into the immune system [175]. Ipilimumab (Yervoy) is a CTLA-4-associated monoclonal antibody (mAbs) that improves the body's immune response to cancer cells. It is widely used for the treatment of skin melanoma and cureently under investigation for other forms of cancers [176]. Some microbes such as B. fragilis, 
B. thetaiotaomicron, B.cepacia, G. formicilis, and F. prausnitzii alter in response to the immune checkpoint inhibitor. Mycobacterium bovis has been used to treat bladder cancer for over a century, and other microbial products have been used for immune activation, apoptosis induction, and vasculogenesis inhibition $[177,178]$. Recent reports suggestedthat the microbiome plays a major role in improving immunotherapy, focusing mainly on PD-1 pathways and checkpoint inhibitor therapy targeting CTLA-4 [179]. Recent observations indicate that the response to checkpoint inhibitors differs greatly between patients. Responses, such as gastrointestinal and liver toxicity associated with checkpoint inhibitor therapy and differences in treatment-related toxicity may also be beneficial [180]. Some studies, for example, understanding the role of Akkermansia muciniphila, a gut microbiome enriched with Bacteroidetes, helps to answer these questions [181]. Bifidobacteria spp. Are known to protect against anti-CTLA-4-associated immune-mediated colitis [182]. Other studies have shown that it is safer to react to PD-1 blockades for healthy bacteria in the intestinal microbiome [183]. In patients with Faecalibacterium prausnitzii, higher loads and lower abundance of Bacteroides after anti-CTLA-4 therapy led higher risk factors for colitis [184]. Bifidobacteria, Akkermansia muciniphila, and Ruminococcaceae bacteria are usually associated with health factors. Those related to immunogenicity are Alistipes, Collinsella and Enterococcietc alters anti-CTLA-4 therapy [185]. The risk of infection and graft-versushost disease (GVHD) after allogeneic hematopoietic stem cell transplantation (ASCT) in hematological malignancies is controlled by gut bacteria. Early applications of systemic broad-spectrum antibiotics are correlated with increased GVHD and mortality associated with transplantation, probably due to the depletion of the gut microbiota of defensive Clostridiales and Blautia species [186]. CTLA-4 Ab injections are sufficiently important to influence the content of microbiomes at the level of the genus. Studies on Burkholderiales and Bacteroidales found that the CTLA-4 blockade rapidly causes a comparative increase in Clostridiales quantity in feces [187]. Quantitative polymerase chain reaction (qPCR) studies have shown that targeting the Bacteroides genus and bacterial species in small intestine mucosa and feces are novel trend to study [188]. Promenent increment of content observed in organisms such as B. uniformis and B. thetaiotaomicron (Bt) from 24 to $48 \mathrm{~h}$ after CTLA-4 $\mathrm{Ab}$ injection in the mucosa of the small intestine [189]. Isolated and distinguished by one of the main regulatory Bacteroides, $B$. fragilis (Bf) was quickly found to be observable by regular colon mucosal PCR, while no increment of CTLA-4 Ab observed [190]. The therapeutic effects of cyclophosphamide administration [191] are decreased by some particular bacterial organisms, such as Parabacteroides distasonis, which drives Treg effects and SFBs that, in turn, drive Th17 responses. In response to cyclophosphamide, certain types of Gram-positive bacteria, such as Enterococcus hirae and Lactobacillus johnsonii, have been reported to increase [192] and carry Th1 memory cells into the lumen. Some bacterial organisms, such as Clostridiales, suppress immune cell responsiveness by activating the development of IL-10 in the intestine and extra-intestine and the differentiation of Tregs [193]. Commensal bacteria also aid in the regulation of systemic immunity in addition to influencing local immunity. B-created polysaccharide (PSA) Bacteroides fragilisis capable of reliably detecting immune defects in germ-free mice linked to Th1/Th2 imbalance and CD4 ${ }^{+} \mathrm{T}$ cell deficiency [194]. E. hirae activates the response of pathogenic Th17 (pTh17) cells and increases the extra-intestinal tissue ratio of cytotoxic T cells/Tregs, while $B$. intestinihominis bacteria helps to strengthen the response to systemic Tc1 and Th1 [195]. The gut microbiome is simultaneously formed and enriched by host immunity. In the case of a mouse model, adaptive immune and innate responses are downregulated with manybacterial enrichment [196]. Recent reports indicate that host immunity can also influence the morphology of certain species of bacteria which, in turn, often hampers the relationship between bacteria and epithelial cells (Figure 4) [151]. Cancer immunotherapy with anti-CTLA-4 antibodies modulates the balance of the microbiota-intestinal barrier by inducing IEC-mediated intestinal epithelial cell (IEL) apoptosis, resulting in disruption of the barrier. In experimental settings (possibly due to pathogenic Th17 cells (pTh17)), barrier perturbation is further increased during the co-blockade of IL-10 signaling or ICOS 
(Inducible T-cell COStimulator) signaling, resulting in higher intestinal toxicity resembling early signs of colitis [151]. (Re)colonization of mice treated with antibiotics by B. fragilis (Bf) and Burkholderiacepacia minimizes the toxicity caused by anti-CTLA-4 mAb (possibly through the plasmacytoid DC ( $\mathrm{pDC}$ ) mobilization ability of $B$. fragilis), which facilitates the proliferation of $\mathrm{ICOS}^{+}$Treg in the lamina propria while retaining good antitumor efficacy (right). Increased bacterial species uptake, for example of $B$. fragilis, due to lamina propria DCs or to the possible DC absorption of soluble bacterial products results in the maturation of DCs and the development of IL-12, enabling T cells such as Th1 cells to be primed/activated (facilitated by the ongoing immune checkpoint blockade). These T cells, possibly cognizant of tumor antigens or cross-reactive bacterial antigens, are involved in antitumor immune responses (Figure 4) [197,198].

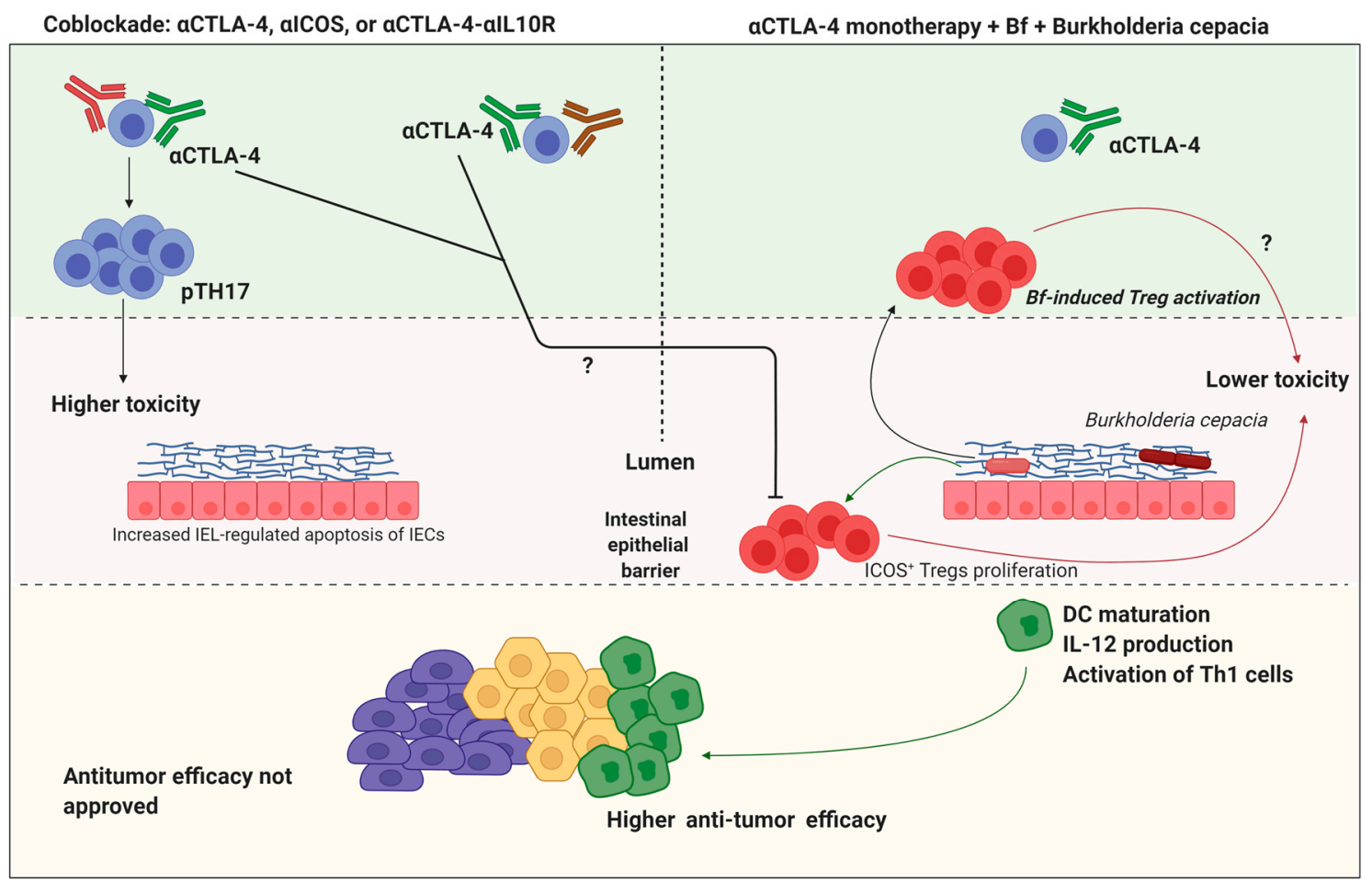

Figure 4. The extent of efficacy and toxicity during the CTLA-4 checkpoint blockade is determined by certain gut microbiotaprofiles.

\subsection{Microbiome Implications in PD-1/PD-L1 Inhibitor-Based Immunotherapy}

PD-1 is a checkpoint protein found in immune T cells. It assists and preserves the protection of T cells from attacking and destroying other cells in the body [198]. There is a significant expression of PD-L1 in several cancer cells, which presumably allows them to evade an immune attack. Recent reports show that monoclonal antibodies targeting either PD-1 or PD-L1 can block this interaction and eventually increase the immune response to cancer cells [199]. In the treatment of variety of cancers, these drugs are a very promising approach. Generally, these medications are administered intravenously by physicians. Cemiplimab (Libtayo), pembrolizumab (Keytruda), and nivoluma are examples of drugs that aid in targeting PD-1 [200]. In the treatment of many forms of cancer, these medications were shown to be effective. New forms of cancer are being examined against these drugs give a ray of hope. Drugs that target PD-L1, namely, durvalumab (Imfinzi), (atezolizumab (Tecentriq), and avelumab (Bavencio) [201] are PD-L1 inhibitors. These medicines have already been shown to be effective in the treatment of different forms of cancer and are waiting to be tested for use against new cancers. Some inosine-related microbiomes have been reported to modulate the effectiveness of these inhibitors [202]. Three bacterial species 
have been shown to increase the effectiveness of immune checkpoint inhibitors, including Bifidobacterium pseudolongum, Lactobacillusjohnsonii and Olsenella [203]. Microbes may be used for the immunotherapy of cancer patients as a successful efficacy booster for PD-1 and PD-L1 inhibitorsCombinations of microbiomes that might boost the efficacy of immunecheck inhibitors should be tested. Microbial adjuvants could be developed to increase the efficacy of inhibitors in the immunotherapy of cancers [204]. Advance research on the microbiome and its efficacy could promote the treatment of cancer on a personalized basis. Microbial distribution in healthy and disease subjects needs to be explored. Food items with enriched microbes responsible for increasing the efficacy of treatment can be provided. More human correlation studies are required to establish the identity of important microbes and their role in treatment (Figure 5) [205,206].

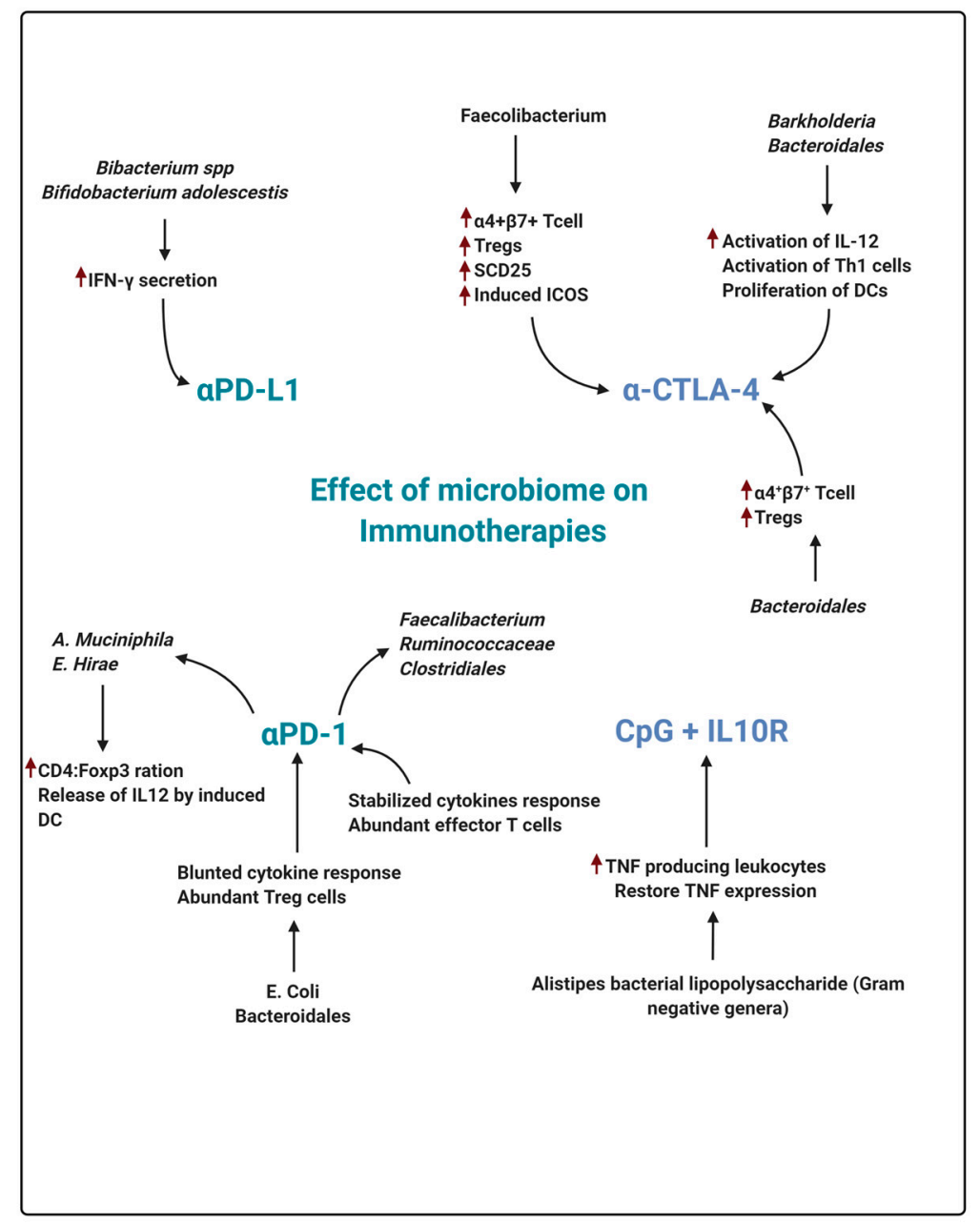

Figure 5. In recent research, unique species of microbiome influences the immune response to four major immunotherapies commonly used and its mechanism. PD-1 programmed death receptor-1, PD-L1: programmed death-ligand 1; CTLA-4: cytotoxic T lymphocyte-associated protein 4; alpPD-1: anti-PD-1 therapy; alpPD-L1: anti-PD-L1 therapy; alpCTLA-4: anti-CTLA-4 therapy; CpG+ alpIL-10R; TLR9 ligand CPG plus anti-IL-10R antibody and various immunotherapy components.

\subsection{Microbiome Implications in Allo-HSCT (AHSCT)}

Due to intense treatment with antibiotics, irradiation, and chemotherapy, some form of disruption in the intestinal microbiota contributes to the creation of rigorous gut graftversus-host disease, often leading to serious infection. This often leads to worse results in patients undergoing allogeneic hematopoietic stem cell transplantation (allo-HSCT). The two main causative agents, Ralstonia pickettii and Staphylococcus haemolyticus, were found to be associated with a higher risk and mortality [207]. Allo-HSCT is a very effective 
approach for the treatment of different forms of hereditary hematopoietic disorders and associated hematological malignancies [208]. Allo-HSCT recipients must undergo intense complete body irradiation and chemotherapy [209] to exterminate latent malignant cells and immunocompetent cells.

In allo-HSCT, three major microbes, namely Neisseria, Prevotella, and Streptococcus, were found to be very high in quantity. The existence of these microbes can exacerbate the stem cells drawn from them. These microbes secrete certain metabolites such as short-chain fatty acids, which affect the incidence of certain diseases and graft rejection. A strong predictor of high risk of development and mortality associated with the introduction of allo-HSCT [210] has now been found based on the microbial diversity present in intestinal microbiota. Therefore, the graft transplant and its success rate are influenced by microbes. However, the precise mechanism of graft rejection through the intervention of microbes has yet to be identified.

\subsection{Microbiome Implications in Probiotic Immunotherapy}

Currently, there are very fewer therapeutic methods available to control and prevent treatment of underlying diseases such as liver, colorectal, oral, and breast cancer. Taking the importance of disease progression into account, the gut-microbiota disease axis has been shown to be a promising target to studythe development of cancertreatment.

\subsubsection{Liver Cancer}

Recently, probiotics have been implemented for re-equilibrating the gut microbiome in the case of chronic liver disease (CLD) by selectively recruiting beneficial bacteria. However, recentreports haveshown the efficacy of probiotics in curing liver diseases both inanimal models and in patients [211]. In the case of rat models of DEN-mediated hepatocarcinogenesis, the administration of VSL\#3 (specifically affecting Lactobacillus paracasei, Lactobacillus acidophilus, Lactobacillus plantarum, Lactobacillus delbrueckii sub sp. Bulgaricus, Bifidobacterium infantis, Bifidobacterium breve, Bifidobacterium longum, and Streptococcus thermophiles) was effective in enteric dysbiosis, decreasing inflammation of the intestine and leading to a decrease in liver tumor growth and its multiplicity [212].

\subsubsection{Breast Cancer (BC)}

Staphylococcus hominis and Enterococcus faecalis have been shown to be inhibited in recent in vitro and in vivo studies, showing the impact of probiotics on breast cancer. The probiotic Lactobacillus reuteri suppresses early-stage cancer and has contributed to an increase in susceptibility to apoptosis in breast cells [213]. The anticancer effects of advanced probiotics on cancer cell lines have been studied by Mendoza et al. They identified the effects of cytotoxicity, the anti-proliferative action of cell cycle arrest, apoptosis, and probiotic effects. Another group (NCT03760653) described the impact of probiotics (Bifidobacterium bifidum, Lactobacillus rhamnosus, Lactobacillus acidophilus and Lactobacillus paracasei) and physical activity on bacterial equilibrium onthe immune system of BC survivors [214].

\subsubsection{Colorectal Cancer (CRC)}

CRC can be inhibited by different kinds of probiotics througha variety of mechanisms Recent studies have shown that probiotics lead to the biotransformation and detoxification in conjunction with carcinogenic mutagens, depending on the secreted glycoproteins, peptidoglycan, and polysaccharides on the surface of probiotics. In order to prevent CRC, probiotics can assist in the down regulation of inflammation and eventually reduce the levels of carcinogenic compounds and metabolites [215]. Recent studies have shown that, in mice treated with Clostridium butyricum and 1,2-two hydrazine hydrochloride, tumor size decreases due to decreased amounts of Th2 and Th17 cells, leading to the inhibition of CD4 ${ }^{+}$ and $\mathrm{CD}^{+} \mathrm{T}$ lymphocytes. This led to decrease secretion of inflammatory factors such as nuclear factor B and IL-22, which jams cell cycles and induces apoptosis of tumor cells [216]. 


\subsubsection{Oral Cancer}

Certain commercially available live probiotic strains of bacterial genera, such as Streptococcus, Bifidobacterium and Lactobacillus can increase the alpha diversity of the oral microbiome without altering its composition [217]. As described earlier, in terms of the gut microbiome, Lactobacillus is a widespread and effective probiotic [218], and has been found to be directly and indirectly associated with dental caries and CRC. Streptococcus oralis is implicated in the infection of cystic fibrosis, and Leptotrichia is implicated in pancreatic cancer. Lactobacillus is favorable to dental caries development without a microenvironment and helps promote better alpha diversity, leading to better oral health [219].

\subsection{Microbiome Implications in CpG-Oligonucleotide (CpG ODN) Immunotherapy}

Early pre-clinical and clinical studies indicate that unmethylated CG dinucleotide (CpG ODN) synthetic oligodeoxynucleotides have a powerful immunostimulatory property and can be used for a variety of treatments for cancer due to potent anticancer activity [220]. In a range of preclinical models, CpG ODNs and microbiome synergy have recently been implicated. Early clinical studies have shown that monoclonal antibodies and CpG ODNs can administered together safely [157]. Studies on preclinical models have shown that when combined with radiation therapy and chemotherapy, CpG ODNs can also improve antitumor activity. A type of pleiotropic cytokine formed by several cells is interleukin-10 (IL-10). IL-10 is well known for controlling the activity of APCs and helping to suppress the proinflammatory cytokine response by delaying T-cell activation [221].

In comparison, in the case of CD8 + TILs cells, tumor progression through mediationof IL-10 signaling can also be suppressed. Therefore, IL-10 also plays an important and paradoxical function in cancer immunotherapy via its potential to inhibit or activate IL-10 signaling [222]. Therefore, the selection of target cells and treatment targets is critical. Due to uncertain therapeutic safety and effectiveness, IL-10 signaling blockades remaina region for explorationand are being used in cancer immunotherapy [223]. The effect of a specific blockade of IL-10R on the CD4 + T cell response against hepatitis C virus antigens was evaluated in an ex vivo clinical trial [224]. The results showed that inhibiting IL-10R could induce the proliferation of CD4 $+\mathrm{T}$ cells and lead to increased development of interferon-gamma (IFN- $\gamma$ ) against the hepatitis $C$ virus [224]. In the case of immunostimulatory signaling of TLR9 in immune cells modulating the tumor microenvironment in cancer patients, recent studies indicate the involvement of several steps of negative regulation [225]. Therefore, in conjunction with techniques that target immune control point regulation, the $\mathrm{CpG}$ ODN-based technique has a great advantage. The latest clinical trials of $\mathrm{CpG}$ ODNs in combination with immune checkpoint inhibitors have potential for future cancer immunotherapy, which is effective and comparatively safe [226]. The role of the microbiome in the efficacy of CpG ODN-based treatment still needs to be ascertained.

\subsection{Microbiome Implications in Adoptive Cell Therapy (ACT)}

ACT is usually referred to as the alteration and extension of in vitro-induced cancercognate lymphocyte infusion to enhance immune function [227]. Tumor infiltrating lymphocytes (TILs), bispecific T-cell engagers (BiTEs), and chimeric antigen receptor (CAR) T-cells [228] are promising approaches for cancer treatment. The isolation accompanied by the ex vivo expansion of tumor-specific T-cells induces ACT. To eliminate cancer, these cells are now transfused back to the patient. CAR T-cells are autologous T-cells that have been previously engineered and redirected to a tumor-specific antigen, in order to enhance antitumor immune response [229]. The link between ACT efficacy and gut microbiome therapy was first demonstrated by Herranz et al. ACT has been found to be successful in HAR mice receiving ACT and in almost completely suppressing tumor growth. Assessment of fecal matter bacteria has shown that, compared to JAX mice, HAR mice have a more diverse variety of Bacteroidetes [230]. The level of gram-positive bacteria and gram-negative bacteria intervention widely affected the result of ACT. ACT efficacy improved when the 
bacterial composition was significantly modified after the decrease inGram-positive bacteria resulting fromintervention with antibiotics [231]. In conclusion, intestinal microbiota plays a vital function in ACT's antitumor efficacy.

\subsection{Microbiome Implications in Fecal Microbiota Transplantation (FMT)}

Fecal microbiota transplantation (FMT) has been successfully implemented in patients with $C$. difficile infection (CDI) and consequential infacilitating clinical improvements andthe restoration of eubiosisand seems to be superior to standard antibiotic therapy [232]. FMT is a kind of infusion of a solution, created with microbiota fecal matter obtained from a donor, into the recipient's intestinal tract. This directly helps alter the recipient's microbial composition and impacts health [233]. Metagenomics analysis revealed that there is a prominent reduction indiversity and richness in the case of gut microbiome related to CDI patients, as compared with healthy persons [234]. This dysbiosis process is also characterized by the enhancement of Proteobacteria species anda decrement in Bacteroidetes and Firmicutes species [235]. Thesuccess of FMT is supported by the restored communities of Bacteroidetes and Firmicutes followed by a decrement in Proteobacteria that outcompetes C. difficile. Nowadays, FMT has been used in clinical trials for additional diseases such as cirrhosis and NASH124 [236].

\subsection{Microbiome-Host Crosstalk, Signalling and Immunomodulation}

The gut is bidirectionally linked with the central nervous system through well-known "gut-brain axis" (GBA), which includes central nervous system (CNS), the autonomic nervous system (ANS), the entero-endocrine system (EES), the enteric nervous system (ENS), and the hypothalamic pituitary adrenal (HPA) axis. Hormones and neuro-hormones secreted helps in cross talk over GBA and modulate the metabolic activities and gastrointestinal digestive [237]. For that cause, the gut work as complex interface between the gastro-intestinal microbiota and the human body. There is a bidirectional communication system working between gut microbes and host's GBA, in this system gut work as the communication gatekeeper [238]. A host's hormones and neuro-hormones can modify the basic composition of gut microbiome during stress response [239]. The gastro-intestinal entero-endocrine cells secrete over 30 different peptide/molecules /hormones (histidine to histamine or glutamate to $\gamma$-aminobutyric acid (GABA), short-chain fatty acids (SCFAs), vitamin $\mathrm{K}$ etc) involved in a number of functions, like neuromodulation motility, digestive functions and gastro-intestinal [240]. There are a number of signaling pathways that may affect gut microbiome and its metabolites that could perturb the normal physiological functions of host. Interestingly, a number of these processes are controlled by the mammalian target of rapamycin (mTOR) [241]. The mTOR pathway is well-known and is involved in many intracellular processes like transcription, translation, cell growth, cytoskeletal organization autophagy and environmental changes [242]. Crosstalk between the gut microbiota and the mTOR pathway impacts the body's homeostasis, thus, leading to undesirable complications, not only in cancer, but also in a number of other diseases, like obesity, diabetes, colon and pancreatic immune system malfunctioning and ageing. There are a limited number of research studies regarding the communication between gut microbiota and the mTOR pathway, that elucidate mTOR signaling in microbiota-associated metabolic and immune regulations [243]. Gut microbiome also plays a significant role in the immune system in controlling the functionality and development of gut-associated lymphoid tissues (GALT), including mesenteric lymph nodes, isolated lymphoid follicles, and Peyer's patches $[244,245]$. Apart from this gut microbiome secreted products are very important for the immune system to differentiate self from nonself (invaders) at very young stage and activation and maintenance of innate hematolymphoid cells (ILC1, 2, and 3), cytotoxic and noncytotoxic and helper lymphoid cells and natural killer (NK) cells [246]. Natural killer cells and ILC1 produce large quantity of IFN- $\gamma$, Reg III $\gamma$, defensins antimicrobial peptides (AMPs), granulysin, and lysozyme, that together play very crucial role in regulation of immune surveillance and microbial ecology [247]. Microbiota also produces vast number 
of epigenetically active metabolites, like folate, pyridoxine $\left(B_{6}\right)$, folate $\left(B_{9}\right)$, cobalamin $\left.\left(B_{12}\right)\right)$ $A$ and $B$ vitamins (including riboflavin $\left(B_{2}\right)$, niacin $\left(B_{3}\right)$, and pantothenic acid $\left(B_{5}\right)$, that participate in regulation the genetic responses to environmental signalsand activity of host chromatin-modulating enzymes [248]. Acetyl-CoA formed in number of metabolic processes work as acetyl donor for histone modification (acetylation and deacetylation) that is catalyzed by enzyme histone acetyltransferases. Methionine glycine and serine are substrates for DNA methylation and demethylation enzymes [249,250].

\subsection{Microbiome and Cancer Prevention}

A number of microbiomes-derived molecules participate in anti-tumor activity. Anticancer therapies are designed for effective eradication of the cancer control and prevention. As available anti-cancer treatment has been proven to toxic also towards normal cells, microbiomes use may be effective to combat with malignancy.

Microbial-derived SCFAs have quite effective anti-cancer property. For instance, gut bacterial butyrate and propionate inhibit host's tumor cells histone deacetylases with a general anti-cancer effect. Such a mechanism of anti-tumoral in vitro and in vivo effect of butyrate is well-established in case of both colorectal cancer (CRC) and lymphoma [251,252]. Widely studied bacterial lipopolysaccharide (LPS), a major factor of the outer membrane in gram-negative bacteria, helps in activation of the host's cell surface receptor toll-like receptor 4 (TLR4), thus in turn activating immune $\mathrm{T}$ cell-mediated response against a number of cancer cells [162]. Similarly, the monophosphoryl lipid A (MPL) secreted from Salmonella enterica has been widely used as adjuvant along with vaccine against anticervical carcinoma [253]. Furthermore, bacterial derived pyridoxine, a group B vitamin, helps in modulation of host's antitumoral immunosurveillance [254]. Ferricrome metabolite secreted from Lactobacillus casei, able to induce apoptosis in tumor cells through JNK pathway activation [255]. Lactobacilli may stimulate host's immune cells such as dendritic cells (DC) or TH1 response and NK cells that leads to the elimination of cancerous cells. Heat-inactivated microorganisms (Streptococci) were injected intratumorally for in clinical trial in humans to combat cancer [256,257]. Moreover, Mycobacterium bovis been successfully implicated into bladder of patients, to cure bladder tumor [258,259]. Similarly, Oral administration of Lactobacillus casei led to decrement of superficial bladder cancer recurrence [260-263]. An underlying mechanism involves the direct bacterial stimulation of host's macrophages and NK cells that triggers strong antitumoral immune response [264]. Intradermal injection of Mycobacterium implicated in case of melanoma and in pancreatic. Ductal carcinoma induces antitumoral immune based response, acting on host's cytotoxic $T$ cells and antigen presenting cells (APCs) [264-266]. Anti-tumoral immune response and also have a direct cytotoxic effect on the tumor cells, by administration of attenuated and/or genetically modified Salmonella typhimurium [267-269].

\section{Summary and Concluding Remarks}

Although a series of recent studies has been performed on gut microbiome that affects cancer immunotherapy, still much remains unexplored. The mode of action of microbial species that modulates the betterment of immune responses still needs to be understood. Microbes are indispensable in the human gut and for various physiological functions of the human body. Human microbiomes vary among individuals. Various environmental conditions also define their role in the gut. These microbes have a direct impact on various metabolic reactions inside the cell and thus influence the physiology of the cell and cancer treatment by radiation, chemotherapy, immunotherapy, or probiotics. More efforts are required to establish role of each microbes or groups of microbes in different kinds of cancer. Physiological responses to immunotherapy, antibiotic, radiation, and chemotherapy in microbes need to be explored. The gut microbiomecan work as a useful analytical biomarker in immunotherapy. They could be easily manipulated or changed to improve the efficacy of immunotherapy or to minimize side effects during treatment. Basic and multifactorial research can lead to potential treatmentsforcommon 
cancers. Multidimensional, microbial, molecular, and immunological studies for each kind of cancer need to be conducted. This could help lead to cures, and thus, the realization of the potential of precision and personalized medicine. At present, the enhancement of immune system activity in the diagnosis, cure, and treatment of cancer is of urgent interest. There are several available immunotherapy strategies that involve the manipulation of diverse pathways or molecules. Recently, the consideration of gut microbiomes in immunotherapy has shown a predominated impact on clinical therapeutics. The immunological status of the host, tumor invasion status and biology of the malignancy work as determining factors for individualized therapy. In future, we anticipate that the implementation of a commensal microbiotomewill be a game changer affecting every facet of medical and clinical studies. Analysis of the basic composition of the gut microbiome could lead to accurate evaluations of cancer patients' healthand will probably help in predicting immune responses and their related adverse effects during cancer therapy. Conclusively, we can say that microbiome explorations might lead to the early treatment of various cancers. However, more research is needed globally to reach conclusions about microbes and establish possible treatments.

Funding: The author extends his appreciation to the Deputyship for Research \& Innovation, Ministry of Education in Saudi Arabia for funding this research work through the project number (871).

Data Availability Statement: No new data were created or analyzed in this study. Data sharing is not applicable to this article.

Acknowledgments: The author acknowledges the support from the Deputyship for Research \& Innovation in Ministry of Education and the King Abdulaziz University, Jeddah, Saudi Arabia.

Conflicts of Interest: The author declare no conflict of interest.

$\begin{array}{ll}\text { Abbreviation } & \\ \text { CTLA-4 } & \text { Cytotoxic T-lymphocyte antigen-4 } \\ \text { GBA } & \text { Gut Brain Axis } \\ \text { EBV } & \text { Epstein-Barr virus } \\ \text { HIV } & \text { Human Immunodeficiency Virus } \\ \text { HPV } & \text { Human Papilloma } \\ \text { HPTLV-1 } & \text { Type 1 human T-cell lymphotropic virus } \\ \text { Hb-B } & \text { Hepatitis B } \\ \text { Hb-C } & \text { Hepatitis C } \\ \text { DMAB } & \text { 3, 2'-dimethyl-4-aminobiphenol } \\ \text { NHMI } & \text { Nitrosoheptamethyleneimine } \\ \text { DEN } & \text { N-nitrosodiethylamine } \\ \text { COPD } & \text { Chronic obstructive pulmonary disease } \\ \text { CCl4 } & \text { Carbon Tetra Chloride } \\ \text { DCA } & \text { Deoxycholic Acid } \\ \text { DNA } & \text { Deoxyribonucleic Acid } \\ \text { MALT } & \text { Mucosa-associated lymphoid tissue } \\ \text { ISPID } & \text { Immunoproliferative small intestinal disease } \\ \text { TNF } & \text { Tumor Necrosis Factor } \\ \text { MAMP } & \text { Microbiome associated molecular pattern } \\ \text { TLR } & \text { Toll Like Receptors } \\ \text { LPS } & \text { Lipopolysaccharides } \\ \text { CRC } & \text { Colorectal Cancer } \\ \text { SCFA } & \text { Short Chain Fatty Acids } \\ \text { DSS } & \text { Dextran Sulfate Sodium } \\ \text { AOM } & \text { Azoxymethane } \\ \text { TIGIT } & \text { T cell immunoreceptor with Ig and ITIM domains } \\ \text { IL } & \text { Interleukin } \\ \text { BC } & \text { Breast Cancer } \\ \text { rRNA } & \text { ribosomal Ribonucleic Acid } \\ & \end{array}$




$\begin{array}{ll}\text { NAFLD } & \text { Non-alcoholic liver fatty liver disease } \\ \text { HCC } & \text { Hepatocellular carcinoma } \\ \text { mAbs } & \text { monoclonal Antibodies } \\ \text { PD-1 } & \text { programmed cell death protein1 } \\ \text { PD-L1 } & \text { programmed cell death ligand protein 1 } \\ \text { ICIs } & \text { Immune Check point Inhibitors } \\ \text { TME } & \text { Tumor Microenvironment } \\ \text { APCs } & \text { Antigen Presenting Cells } \\ \text { FMT } & \text { Faecal Microbial Transplantation } \\ \text { HSCT } & \text { hematopoietic stem cell transplantation } \\ \text { MDACC } & \text { MD Anderson Cancer Centre } \\ \text { ICB } & \text { immune checkpoint blockade } \\ \text { GVHD } & \text { Graft versus host disease } \\ \text { Th17 } & \text { Thyroxin receptor 17 } \\ \text { pDC } & \text { plasmacytoid DC (Dendritic cells) } \\ \text { TILs } & \text { Tumor Infiltrating Lymphocytes } \\ \text { BiTEs } & \text { Bispecific T-cell engagers } \\ \text { CAR } & \text { Chimeric Antigen Receptor } \\ \text { ACT } & \text { Adoptive Cell Therapy } \\ \text { CDI } & \text { Clostridium difficali infection } \\ \text { CNS } & \text { Central Nervous System } \\ \text { ANS } & \text { Autonomous Nervous System } \\ \text { ENS } & \text { Enteric Nervous System } \\ \text { GABA } & \text { Gama Amino Butyric Acid } \\ \text { mTOR } & \text { mammalian target of rapamycin } \\ \text { GALT } & \text { Gut Associated lymphoid tissues } \\ \text { NK } & \text { Natural Killer cells } \\ \text { DC } & \text { Dendritic cells } \\ \text { MPL } & \text { Monophosphoryl Lipid } \\ & \end{array}$

\section{References}

1. Zitvogel, L.; Daillère, R.; Roberti, M.P.; Routy, B.; Kroemer, G. Anticancer effects of the microbiome and its products. Nat. Rev. Genet. 2017, 15, 465-478. [CrossRef]

2. Brown, E.M.; Sadarangani, M.; Finlay, B.B. The role of the immune system in governing host-microbe interactions in the intestine. Nat. Immunol. 2013, 14, 660-667. [CrossRef]

3. Matamoros, S.; Gras-Leguen, C.; Le Vacon, F.; Potel, G.; de La Cochetiere, M.F. Development of intestinal microbiota in in-fants and its impact on health. Trends Microbiol. 2013, 21, 167-173. [CrossRef]

4. Walker, R.W.; Clemente, J.C.; Peter, I.; Loos, R.J. The prenatal gut microbiome: Are we colonized with bacteria in utero? Pediatric Obes. 2017, 12, 3-17. [CrossRef]

5. Purchiaroni, F.; Tortora, A.; Gabrielli, M.; Bertucci, F.; Gigante, G.; Ianiro, G.; Ojetti, V.; Scarpellini, E.; Gasbarrini, A. The role of intestinal microbiota and the immune system. Eur. Rev. Med. Pharmacol. Sci. 2013, 17, 323-333. [PubMed]

6. $\mathrm{Wu}, \mathrm{H} .-\mathrm{J} . ; \mathrm{Wu}, \mathrm{E}$. The role of gut microbiota in immune homeostasis and autoimmunity. Gut Microbes 2012, 3, 4-14 [CrossRef] [PubMed]

7. De Kivit, S.; Tobin, M.C.; Forsyth, C.; Keshavarzian, A.; Landay, A.L. Regulation of Intestinal Immune Responses through TLR Activation: Implications for Pro- and Prebiotics. Front. Immunol. 2014, 5, 60. [CrossRef] [PubMed]

8. Rowland, I.; Gibson, G.; Heinken, A.; Scott, K.; Swann, J.; Thiele, I.; Tuohy, K. Gut microbiota functions: Metabolism of nu-trients and other food components. Eur. J. Nutr. 2018, 57, 1-24. [CrossRef]

9. Cussotto, S.; Sandhu, K.V.; Dinan, T.G.; Cryan, J.F. The Neuroendocrinology of the Microbiota-Gut-Brain Axis: A Behavioural Perspective. Front. Neuroendocr. 2018, 51, 80-101. [CrossRef]

10. Ahmad, A.F.; Dwivedi, G.; O'Gara, F.; Caparros-Martin, J.; Ward, N.C. The gut microbiome and cardiovascular disease: Cur-rent knowledge and clinical potential. Am. J. Physiol. Heart Circ. Physiol. 2019, 317, H923-H938. [CrossRef]

11. Sharma, M.; Li, Y.; Stoll, M.L.; Tollefsbol, T.O. The epigenetic connection between the gut microbiome in obesity and diabe-tes. Front. Genet. 2020, 10, 1329. [CrossRef] [PubMed]

12. Clapp, M.; Aurora, N.; Herrera, L.; Bhatia, M.; Wilen, E.; Wakefield, S. Gut microbiota's effect on mental health: The gut-brain axis. Clin. Pr. 2017, 7, 987. [CrossRef] [PubMed]

13. Rinninella, E.; Raoul, P.; Cintoni, M.; Franceschi, F.; Miggiano, G.A.; Gasbarrini., A.; Mele, M.C. What is the healthy gut mi-crobiota composition? A changing ecosystem across age, environment, diet, and diseases. Microorganisms 2019, 7, 14. [CrossRef] [PubMed]

14. Sears, C.L.; Garrett, W.S. Microbes, Microbiota, and Colon Cancer. Cell Host Microbe 2014, 15, 317-328. [CrossRef] [PubMed] 
15. Tsilimigras, M.C.B.; Fodor, A.; Jobin, C. Carcinogenesis and therapeutics: The microbiota perspective. Nat. Microbiol. 2017, 2, 1-10. [CrossRef]

16. Boursi, B.; Mamtani, R.; Haynes, K.; Yang, Y.-X. Recurrent antibiotic exposure may promote cancer formation-Another step in understanding the role of the human microbiota? Eur. J. Cancer 2015, 51, 2655-2664. [CrossRef]

17. Saus, E.; Iraola-Guzmán, S.; Willis, J.R.; Brunet-Vega, A.; Gabaldón, T. Microbiome and colorectal cancer: Roles in carcinogenesis and clinical potential. Mol. Asp. Med.. [CrossRef]

18. Yang, Y.; Jobin, C. Novel insights into microbiome in colitis and colorectal cancer. Curr. Opin. Gastroenterol. 2017, 33, 422-427. [CrossRef]

19. Brennan, C.A.; Garrett, W.S. Gut Microbiota, Inflammation, and Colorectal Cancer. Annu. Rev. Microbiol. 2016, 70, 395-411. [CrossRef]

20. Dimitrov, D.V. The Human Gutome: Nutrigenomics of the Host-Microbiome Interactions. OMICS: A J. Integr. Biol. 2011, 15, 419-430. [CrossRef]

21. Castellarin, M.; Warren, R.L.; Freeman, J.D.; Dreolini, L.; Krzywinski, M.; Strauss, J.; Barnes, R.; Watson, P.; Allen-Vercoe, E.; Moore, R.A.; et al. Fusobacteriumnucleatum infection is prevalent in human colorectal carcinoma. Genome Res. 2012, 22, 299-306. [CrossRef] [PubMed]

22. Kostic, A.D.; Gevers, D.; Pedamallu, C.S.; Michaud, M.; Duke, F.; Earl, A.M.; Ojesina, A.I.; Jung, J.; Bass, A.J.; Tabernero, J.; et al. Genomic analysis identifies association of Fusobacterium with colorectal carcinoma. Genome Res. 2011, 22, $292-298$. [CrossRef] [PubMed]

23. Balamurugan, R.; Rajendiran, E.; George, S.; Samuel, G.V.; Ramakrishna, B.S. Real-time polymerase chain reaction quantifi-cation of specific butyrate-producing bacteria, Desulfovibrio and Enterococcusfaecalis in the feces of patients with colorectal cancer. J. Gastroenterol. Hepatol. 2008, 23, 1298-1303. [CrossRef] [PubMed]

24. Wang, T.; Cai, G.; Qiu, Y.; Fei, N.; Zhang, M.; Pang, X.; Jia, W.; Cai, S.; Zhao, L. Structural segregation of gut microbiota be-tween colorectal cancer patients and healthy volunteers. ISME J. 2012, 6, 320-329. [CrossRef]

25. Wu, N.; Yang, X.; Zhang, R.; Li, J.; Xiao, X.; Hu, Y.; Chen, Y.; Yang, F.; Lu, N.; Wang, Z.; et al. Dysbiosis Signature of Fecal Microbiota in Colorectal Cancer Patients. Microb. Ecol. 2013, 66, 462-470. [CrossRef]

26. Lee, S.A.; Liu, F.; Riordan, S.M.; Lee, C.S.; Zhang, L. Global Investigations of Fusobacterium nucleatum in Human Colorectal Cancer. Front. Oncol. 2019, 9, 566. [CrossRef]

27. Yang, Z.; Ji, G. Fusobacterium nucleatum-positive colorectal cancer. Oncol. Lett. 2019, 18, 975-982.

28. Khan, A.A.; Shrivastava, A.; Khurshid, M. Normal to cancer microbiome transformation and its implication in cancer diag-nosis. Biochim. Biophys. Acta. 2012, 1826, 331-337.

29. Sharma, V.; Chauhan, V.S.; Nath, G.; Kumar, A.; Shukla, V.K. Role of bile bacteria in gallbladder carcinoma. Hepato Gastroenterol. 2007, 54, 1622-1625.

30. Narikiyo, M.; Tanabe, C.; Yamada, Y.; Igaki, H.; Tachimori, Y.; Kato, H.; Muto, M.; Montesano, R.; Sakamoto, H.; Nakajima, Y.; et al. Frequent and preferential infection of Treponema denticola, Streptococcus mitis, and Streptococcus anginosus in esophageal cancers. Cancer Sci. 2004, 95, 569-574. [CrossRef]

31. Macfarlane, S.; Furrie, E.; Macfarlane, G.T.; Dillon, J.F. Microbial Colonization of the Upper Gastrointestinal Tract in Patients with Barrett's Esophagus. Clin. Infect. Dis. 2007, 45, 29-38. [CrossRef] [PubMed]

32. Anderson, L.A.; Murphy, S.J.; Johnston, B.T.; Watson, R.G.; Ferguson, H.R.; Bamford, K.B.; Ghazy, A.; McCarron, P.; McGui-gan, J.; Reynolds, J.V.; et al. Relationship between Helicobacter pylori infection and gastric atrophy and the stages of the oe-sophageal inflammation, metaplasia, adenocarcinoma sequence: Results from the FINBAR case-control study. Gut 2008, 57, 734-739. [CrossRef] [PubMed]

33. Mager, D.L.; Haffajee, A.; Devlin, F.F.M.P.M.; Norris, C.M.; Posner, M.R.; Goodson, J.M. The salivary microbiota as a diagnostic indicator of oral cancer: A descriptive, non-randomized study of cancer-free and oral squamous cell carcinoma subjects. J. Transl. Med. 2005, 3, 27. [CrossRef] [PubMed]

34. Gong, H.-L.; Shi, Y.; Zhou, L.; Wu, C.-P.; Cao, P.-Y.; Tao, L.; Xu, C.; Hou, D.-S.; Wang, Y.-Z. The Composition of Microbiome in Larynx and the Throat Biodiversity between Laryngeal Squamous Cell Carcinoma Patients and Control Population. PLoS ONE 2013, 8, e66476. [CrossRef]

35. Farrell, J.J.; Zhang, L.; Zhou, H.; Chia, D.; Elashoff, D.; Akin, D.; Paster, B.J.; Joshipura, K.; Wong, D.T. Variations of oral mi-crobiota are associated with pancreatic diseases including pancreatic cancer. Gut 2012, 61, 582-588. [CrossRef]

36. Ou, J.; Carbonero, F.; Zoetendal, E.G.; Delany, J.P.; Wang, M.; Newton, K.; Gaskins, H.R.; O'Keefe, S.J. Diet, microbiota, and microbial metabolites in colon cancer risk in rural Africans and African Americans. Am. J. Clin. Nutr. 2013, 98, 111-120. [CrossRef]

37. Manzoor, S.S.; Doedens, A.; Burns, M.B. The promise and challenge of cancer microbiome research. Genome Biol. 2020, 21, 1-22. [CrossRef]

38. Kim, N.H.; Park, J.P.; Jeon, S.H.; Lee, Y.J.; Choi, H.J.; Jeong, K.M.; Lee, J.G.; Choi, S.P.; Lim, J.H.; Kim, Y.H.; et al. Purulent Pericarditis Caused by Group G Streptococcus as an Initial Presentation of Colon Cancer. J. Korean Med. Sci. 2002, 17, 571-573. [CrossRef]

39. Kanazawa, K.; Konishi, F.; Mitsuoka, T.; Terada, A.; Itoh, K.; Narushima, S.; Kumemura, M.; Kimura, H. Factors influencing the development of sigmoid colon cancer: Bacteriologic and biochemical studies. Cancer 1996, 8, 1701-1706. [CrossRef] 
40. Scanlan, P.D.; Shanahan, F.; Clune, Y.; Collins, J.K.; O'Sullivan, G.C.; O’Riordan, M.; Holmes, E.; Wang, Y.; Marchesi, J.R. Cultureindependent analysis of the gut microbiota in colorectal cancer and polyposis. Environ. Microbiol. 2008, 10, 789-798. [CrossRef]

41. Nath, G.; Gulati, A.K.; Shukla, V.K. Role of bacteria in carcinogenesis, with special reference to carcinoma of the gallbladder. World J. Gastroenterol. WJG 2010, 16, 5395. [CrossRef] [PubMed]

42. Lopetuso, L.R.; Severgnini, M.; Pecere, S.; Ponziani, F.R.; Boškoski, I.; Larghi, A.; Quaranta, G.; Masucci, L.; Ianiro, G.; Camboni, T.; et al. Esophageal microbiome signature in patients with Barrett's esophagus and esophageal adenocarcinoma. PLoS ONE 2020, 15, e0231789. [CrossRef] [PubMed]

43. Zhang, L.; Liu, Y.; Zheng, H.J.; Zhang, C.P. The Oral Microbiota May Have Influence on Oral Cancer. Front. Cell. Infect. Microbiol. 2020, 9, 476. [CrossRef] [PubMed]

44. Gong, H.; Shi, Y.; Zhou, X.; Wu, C.; Cao, P.; Xu, C.; Hou, D.; Wang, Y.; Zhou, L. Microbiota in the Throat and Risk Factors for Laryngeal Carcinoma. Appl. Environ. Microbiol. 2014, 80, 7356-7363. [CrossRef]

45. Tuominen, H.; Rautava, J. Oral Microbiota and Cancer Development. Pathobiology 2020, 1-11. [CrossRef]

46. Plottel, C.S.; Blaser, M.J. Microbiome and Malignancy. Cell Host Microbe 2011, 10, 324-335. [CrossRef]

47. Han, S.; Gao, J.; Zhou, Q.; Liu, S.; Wen, C.; Yang, X. Role of intestinal flora in colorectal cancer from the metabolite perspec-tive: A systematic review. Cancer Manag. Res. 2018, 10, 199. [CrossRef]

48. Oke, S.; Martin, A. Insights into the role of the intestinal microbiota in colon cancer. Ther. Adv. Gastroenterol. 2017, 10, 417-428. [CrossRef]

49. Francescone, R.; Hou, V.; Grivennikov, S.I. Microbiome, Inflammation, and Cancer. Cancer J. 2014, 20, 181-189. [CrossRef]

50. Reddy, B.S.; Watanabe, K. Effect of Intestinal Microflora on 3,2'-Dimethyl-4-aminobiphenyl-Induced Carcinogenesis in F344 Rats2. J. Natl. Cancer Inst. 1978, 61, 1269-1271. [CrossRef]

51. Schreiber, H.; Nettesheim, P.; Lijinsky, W.; Richter, C.B.; Walburg, J.H.E. Induction of Lung Cancer in Germfree, Specific-PathogenFree, and Infected Rats by N-Nitrosoheptamethyleneimine: Enhancement by Respiratory Infection2. J. Natl. Cancer Inst. 1972, 49, 1107-1114. [CrossRef] [PubMed]

52. Lofgren, J.L.; Whary, M.T.; Ge, Z.; Muthupalani, S.; Taylor, N.S.; Mobley, M.; Potter, A.; Varro, A.; Eibach, D.; Suerbaum, S.; et al. Lack of commensal flora in Helicobacter pylori-infected INS-GAS mice reduces gastritis and delays intraepithelial neo-plasia. Gastroenterology 2011, 140, 210-220. [CrossRef] [PubMed]

53. Lee, C.W.; Rickman, B.; Rogers, A.B.; Ge, Z.; Wang, T.C.; Fox, J.G. Helicobacter pylori eradication prevents progression of gas-tric cancer in hypergastrinemic INS-GAS mice. Cancer Res. 2008, 68, 3540-3548. [CrossRef] [PubMed]

54. Dapito, D.H.; Mencin, A.; Gwak, G.-Y.; Pradere, J.-P.; Jang, M.-K.; Mederacke, I.; Caviglia, J.M.; Khiabanian, H.; Adeyemi, A.; Bataller, R.; et al. Promotion of Hepatocellular Carcinoma by the Intestinal Microbiota and TLR4. Cancer Cell 2012, 21, 504-516. [CrossRef] [PubMed]

55. Yu, L.-X.; Yan, H.-X.; Liu, Q.; Yang, W.; Wu, H.-P.; Dong, W.; Tang, L.; Lin, Y.; He, Y.-Q.; Zou, S.-S.; et al. Endotoxin accumulation prevents carcinogen-induced apoptosis and promotes liver tumorigenesis in rodents. Hepatology 2010, 52, 1322-1333. [CrossRef]

56. Yoshimoto, S.; Loo, T.M.; Atarashi, K.; Kanda, H.; Sato, S.; Oyadomari, S.; Iwakura, Y.; Oshima, K.; Morita, H.; Hattori, M.; et al. Obesity-induced gut microbial metabolite promotes liver cancer through senescence secretome. Nature 2013, 499, 97-101. [CrossRef]

57. Li, Y.; Kundu, P.; Seow, S.W.; de Matos, C.T.; Aronsson, L.; Chin, K.C.; Kärre, C.; Sven Pettersson, S.; Greicius, G. Gut microbiota accelerate tumor growth via c-jun and STAT3 phosphorylation in APCMin/+ mice. Carcinogenesis 2012, 33, 1231-1238. [CrossRef]

58. Chen, G.Y.; Shaw, M.H.; Redondo, G.; Nunez, G. The innate immune receptor Nod1 protects the intestine from inflamma-tioninduced tumorigenesis. Cancer Res. 2008, 68, 10060-10067. [CrossRef]

59. Kostovcikova, K.; Kverka, M.; Zakostelska, Z.; Hudcovic, T.; Hrncir, T.; Stepankova, R.; Rossmann, P.; Ridl, J.; Kostovcik, M.; Mrazek, J.; et al. Altered Gut Microbiota Promotes Colitis-Associated Cancer in IL-1 Receptor-Associated Kinase M-Deficient Mice. Inflamm. Bowel Dis. 2013, 19, 1266-1277. [CrossRef]

60. Couturier-Maillard, A.; Thomas Secher, T.; Rehman, A.; Normand, S.; Arcangelis, A.; Haesler, R.; Huot, L.; Grandjean, T.; Bressenot, A.; Delanoye-Crespin, A.; et al. NOD2-mediated dysbiosis predisposes mice to transmissible colitis and colorec-tal cancer. J. Clin. Investig. 2013, 123, 700-711.

61. Cuzick, J.; Otto, F.; Baron, J.A.; Brown, P.H.; Burn, J.; Greenwald, P.; Jankowski, J.; La Vecchia, C.; Meyskens, F.; Senn, H.J.; et al. Aspirin and non-steroidal anti-inflammatory drugs for cancer prevention: An international consensus statement. Lancet Oncol. 2009, 10, 501-507. [CrossRef]

62. Bosetti, C.; Gallus, S.; La Vecchia, C. Aspirin and cancer risk: An updated quantitative review to 2005. Cancer Causes Control 2006, 17, 871-888. [CrossRef] [PubMed]

63. Arthur, J.C.; Perez-Chanona, E.; Mühlbauer, M.; Tomkovich, S.; Uronis, J.M.; Fan, T.-J.; Campbell, B.J.; Abujamel, T.; Dogan, B.; Rogers, A.B.; et al. Intestinal Inflammation Targets Cancer-Inducing Activity of the Microbiota. Science 2012, 338, 120-123. [CrossRef] [PubMed]

64. Rooks, M.G.; Garrett, W.S. Bacteria, food, and cancer. F1000 Biol. Rep. 2011, 3, 12. [CrossRef]

65. Willett, W.C. Diet and cancer: An evolving picture. JAMA 2005, 293, 233-234. [CrossRef]

66. Ma, J.-L.; Zhang, L.; Brown, L.M.; Li, J.-Y.; Shen, L.; Pan, K.-F.; Liu, W.-D.; Hu, Y.; Han, Z.-X.; Crystal-Mansour, S.; et al. Fifteen-Year Effects of Helicobacter pylori, Garlic, and Vitamin Treatments on Gastric Cancer Incidence and Mortality. J. Natl. Cancer Inst. 2012, 104, 488-492. [CrossRef] 
67. Wong, B.C.; Lam, S.K.; Wong, W.M.; Chen, J.S.; Zheng, T.T.; Feng, R.E.; Lai, K.C.; Hu, W.H.; Yuen, S.T.; Leung, S.Y.; et al. Hel-icobacter pylori eradication to prevent gastric cancer in a high-risk region of China: A randomized controlled trial. JAMA 2004, 291, 187-194. [CrossRef]

68. Peek, R.M.; Blaser, M.J. Helicobacter pylori and gastrointestinal tract adenocarcinomas. Nat. Rev. Cancer 2002, 2, 28-37. [CrossRef]

69. Fox, J.G.; Wang, T.C. Inflammation, atrophy, and gastric cancer. J. Clin. Investig. 2007, 117, 60-69. [CrossRef]

70. Lecuit, M.; Abachin, E.; Martin, A.; Poyart, C.; Pochart, P.; Suarez, F.; Bengoufa, D.; Feuillard, J.; Lavergne, A.; Gordon, J.I.; et al. Immunoproliferative Small Intestinal Disease Associated withCampylobacter jejuni. N. Engl. J. Med. 2004, 350, 239-248. [CrossRef]

71. Senff, N.J.; Noordijk, E.M.; Kim, Y.H.; Bagot, M.; Berti, E.; Cerroni, L.; Dummer, R.; Duvic, M.; Hoppe, R.T.; Pimpinelli, N.; et al. European Organization for Research and Treatment of Cancer and International Society for Cutaneous Lymphoma con-sensus recommendations for the management of cutaneous B-cell lymphomas. Blood 2008, 112, 1600-1609. [CrossRef] [PubMed]

72. Ferreri, A.J.; Govi, S.; Pasini, E.; Mappa, S.; Bertoni, F.; Zaja, F.; Montalbán, C.; Stelitano, C.; Cabrera, M.E.; Giordano Resti, A. Chlamydophila psittaci eradication with doxycycline as first-line targeted therapy for ocular adnexae lymphoma: Final results of an international phase II trial. J. Clin. Oncol. 2012, 30, 2988-2994. [CrossRef] [PubMed]

73. Islami, F.; Kamangar, F. Helicobacter pylori and Esophageal Cancer Risk: A Meta-analysis. Cancer Prev. Res. 2008, 1, 329-338. [CrossRef] [PubMed]

74. Caygill, C.; Hill, M.; Braddick, M.; Sharp, J. Cancer mortality in chronic typhoid and paratyphoid carriers. Lancet 1994, 343, 83-84. [CrossRef]

75. Welton, J.; Marr, J.; Friedman, S. Association between hepatobiliary cancer and typhoid carrier state. Lancet 1979, 313, 791-794. [CrossRef]

76. Rao, V.P.; Poutahidis, T.; Ge, Z.; Nambiar, P.R.; Horwitz, B.H.; Fox, J.G.; Erdman, S.E. Proinflammatory CD4+CD45RBhi Lymphocytes Promote Mammary and Intestinal Carcinogenesis in ApcMin/+ Mice. Cancer Res. 2006, 66, 57-61. [CrossRef] [PubMed]

77. Ward, J.M.; Fox, J.G.; Anver, M.R.; Haines, D.C.; George, C.V.; Collins, M.J.J.; Gorelick, P.L.; Nagashima, K.; Gonda, M.A.; Gilden, R.V. Chronic active hepatitis and associated liver tumors in mice caused by a persistent bacterial infection with a novel Helicobacter species. J. Natl. Cancer Inst. 1994, 86, 1222-1227. [CrossRef]

78. Erdman, S.E.; Rao, V.P.; Poutahidis, T.; Rogers, A.B.; Taylor, C.L.; Jackson, E.A.; Ge, Z.; Lee, C.W.; Schauer, D.B.; Wogan, G.N. Nitric oxide and TNF- $\alpha$ trigger colonic inflammation and carcinogenesis in Helicobacter hepaticus-infected, Rag2-deficient mice. Proc. Natl. Acad. Sci. USA 2009, 106, 1027-1032. [CrossRef]

79. Reddy, B.S.; Narisawa, T.; Wright, P.; Vukusich, D.; Weisburger, J.H.; Wynder, E.L. Colon carcinogenesis with azoxymethane and dimethylhydrazine in germ-free rats. Cancer Res. 1975, 35, 287-290.

80. Reddy, B.S.; Weisburger, J.H.; Narisawa, T.; Wynder, E.L. Colon carcinogenesis in germ-free rats with 1,2-dimethylhydrazine and N-methyl-n'-nitro-N-nitrosoguanidine. Cancer Res. 1974, 34, 2368-2372.

81. Vannucci, L.; Stepankova, R.; Kozakova, H.; Fiserova, A.; Rossmann, P.; Tlaskalova-Hogenova, H. Colorectal carcinogenesis in germ-free and conventionally reared rats: Different intestinal environments affect the systemic immunity. Int. J. Oncol. 2008, 32, 609-617. [CrossRef] [PubMed]

82. Dove, W.F.; Clipson, L.; A Gould, K.; Luongo, C.; Marshall, D.J.; Moser, A.R.; A Newton, M.; Jacoby, R.F. Intestinal neoplasia in the ApcMin mouse: Independence from the microbial and natural killer (beige locus) status. Cancer Res. 1997, 57, 812-814. [PubMed]

83. Grivennikov, S.I.; Wang, K.; Mucida, D.; Stewart, C.A.; Schnabl, B.; Jauch, D.; Taniguchi, K.; Yu, G.-Y.; Oesterreicher, C.H.; Hung, K.E.; et al. Adenoma-linked barrier defects and microbial products drive IL-23/IL-17-mediated tumour growth. Nat. Cell Biol. 2012, 491, 254-258. [CrossRef] [PubMed]

84. Ponziani, F.R.; Nicoletti, A.; Gasbarrini, A.; Pompili, M. Diagnostic and therapeutic potential of the gut microbiota in patients with early hepatocellular carcinoma. Ther. Adv. Med Oncol. 2019, 11. [CrossRef] [PubMed]

85. Toffanin, S.; Cornella, H.; Harrington, A.; Llovet, J.; Groszmann, R.; Iwakiri, Y.; Taddei, T. HCC is promoted by bacterial transloca-tion and TLR-4 signaling: A new paradigm for chemoprevention and management. Hepatology 2000, 56, 1998-2000. [CrossRef] [PubMed]

86. Kennedy, E.A.; King, K.Y.; Baldridge, M.T. Mouse Microbiota Models: Comparing Germ-Free Mice and Antibiotics Treatment as Tools for Modifying Gut Bacteria. Front. Physiol. 2018, 9, 1534. [CrossRef]

87. Pragman, A.A.; Kim, H.B.; Reilly, C.S.; Wendt, C.; Isaacson, R.E. The lung microbiome in moderate and severe chronic ob-structive pulmonary disease. PLOS ONE 2012, 7, e47305. [CrossRef]

88. Sethi, S.; Murphy, T.F. Infection in the Pathogenesis and Course of Chronic Obstructive Pulmonary Disease. N. Engl. J. Med. 2008, 359, 2355-2365. [CrossRef]

89. Houghton, A.M. Mechanistic links between COPD and lung cancer. Nat. Rev. Cancer 2013, 13, 233-245. [CrossRef]

90. Melkamu, T.; Qian, X.; Upadhyaya, P.; O'Sullivan, M.G.; Kassie, F. Lipopolysaccharide enhancesmouse lung tumorigenesis: A model for inflammation-driven lung cancer. Vet. Pathol. 2013, 50, 895-902. [CrossRef]

91. Ochi, A.; Nguyen, A.H.; Bedrosian, A.S.; Mushlin, H.M.; Zarbakhsh, S.; Barilla, R.; Zambirinis, C.P.; Fallon, N.C.; Rehman, A.; Pylayeva-Gupta, Y.; et al. MyD88 inhibition amplifies dendritic cell capacity to promote pancreaticbcarcinogenesis via Th2 cells. J. Exp. Med. 2012, 209, 1671-1687. [CrossRef] [PubMed]

92. Michaud, D.S.; Joshipura, K.; Giovannucci, E.; Fuchs, C.S. A Prospective Study of Periodontal Disease and Pancreatic Cancer in US Male Health Professionals. J. Natl. Cancer Inst. 2007, 99, 171-175. [CrossRef] [PubMed] 
93. Ammer-Herrmenau, C.; Pfisterer, N.; Weingarten, M.F.; Neesse, A. The microbiome in pancreatic diseases: Recent advances and future perspectives. United Eur. Gastroenterol. J. 2020, 8, 878-885. [CrossRef] [PubMed]

94. Zhan, Y.; Seregin, S.S.; Chen, J.; Chen, G.Y. Nod1 Limits Colitis-Associated Tumorigenesis by Regulating IFN- $\gamma$ Production. J. Immunol. 2016, 196, 5121-5129. [CrossRef] [PubMed]

95. Udden, S.N.; Peng, L.; Gan, J.-L.; Shelton, J.M.; Malter, J.S.; Hooper, L.V.; Zaki, H. NOD2 Suppresses Colorectal Tumorigenesis via Downregulation of the TLR Pathways. Cell Rep. 2017, 19, 2756-2770. [CrossRef] [PubMed]

96. Hu, B.; Elinav, E.; Huber, S.; Booth, C.J.; Strowig, T.; Jin, C.; Eisenbarth, S.C.; Flavell, R.A. Inflammation-induced tumorigen-esis in the colon is regulated by caspase-1 and NLRC. Proc. Natl. Acad. Sci. USA 2010, 107, 21635-21640. [CrossRef] [PubMed]

97. Zaki, H.; Lamkanfi, M.; Kanneganti, T.-D. The Nlrp3 inflammasome: Contributions to intestinal homeostasis. Trends Immunol. 2011, 32, 171-179. [CrossRef]

98. Zaki, H.; Vogel, P.; Malireddi, R.K.S.; Body-Malapel, M.; Anand, P.K.; Bertin, J.; Green, D.R.; Lamkanfi, M.; Kanneganti, T.-D. The NOD-Like Receptor NLRP12 Attenuates Colon Inflammation and Tumorigenesis. Cancer Cell 2011, 20, 649-660. [CrossRef]

99. Chen, G.Y.; Liu, M.; Wang, F.; Bertin, J.; Núñez, G. A Functional Role for Nlrp6 in Intestinal Inflammation and Tumorigenesis. J. Immunol. 2011, 186, 7187-7194. [CrossRef]

100. Zhan, Y.; Chen, P.J.; Sadler, W.D.; Wang, F.; Poe, S.; Núñez, G.; Eaton, K.A.; Chen, G.Y. Gut microbiota protects against gas-trointestinal tumorigenesis caused by epithelial injury. Cancer Res. 2013, 73, 7199-7210. [CrossRef]

101. Mima, K.; Nishihara, R.; Qian, Z.R.; Cao, Y.; Sukawa, Y.; Nowak, J.A.; Yang, J.; Dou, R.; Masugi, Y.; Song, M.; et al. Fusobac-terium nucleatum in colorectal carcinoma tissue and patient prognosis. Gut 2016, 65, 1973-1980. [CrossRef] [PubMed]

102. Mima, K.; Sukawa, Y.; Nishihara, R.; Qian, Z.R.; Yamauchi, M.; Inamura, K.; Kim, S.A.; Masuda, A.; Nowak, J.A.; Nosho, K.; et al. Fusobacterium nucleatum and T Cells in Colorectal Carcinoma. JAMA Oncol. 2015, 1, 653-661. [CrossRef] [PubMed]

103. Galon, J.; Costes, A.; Sanchez-Cabo, F.; Kirilovsky, A.; Mlecnik, B.; Lagorce-Pagès, C.; Tosolini, M.; Camus, M.; Berger, A.; Wind, P.; et al. Type, Density, and Location of Immune Cells Within Human Colorectal Tumors Predict Clinical Outcome. Science 2006, 313, 1960-1964. [CrossRef] [PubMed]

104. Fragomeni, S.M.; Sciallis, A.; Jeruss, J.S. Molecular Subtypes and Local-Regional Control of Breast Cancer. Surg. Oncol. Clin. North Am. 2018, 27, 95-120. [CrossRef]

105. Lacey, J.V.; Kreimer, A.R.; Buys, S.S.; Marcus, P.M.; Chang, S.-C.; Leitzmann, M.F.; Hoover, R.N.; Prorok, P.; Berg, C.D.; Hartge, P. Breast cancer epidemiology according to recognized breast cancer risk factors in the Prostate, Lung, Colorectal and Ovarian (PLCO) Cancer Screening Trial Cohort. BMC Cancer 2009, 9, 84-88. [CrossRef]

106. Rubinstein, M.R.; Wang, X.; Liu, W.; Hao, Y.; Cai, G.; Han, Y.W. Fusobacteriumnucleatum promotes colorectal carcinogenesis by modulating E-cadherin/ $\beta$-catenin signaling via its Fad Aadhesin. Cell Host Microbe 2013, 14, 195-206.

107. Nougayrède, J.-P.; Homburg, S.; Taieb, F.; Boury, M.; Brzuszkiewicz, E.; Gottschalk, G.; Buchrieser, C.; Hacker, J.; Ulrich Do-brindt, U.; Oswald, E.; et al. Escherichiacoli induces DNA double-strand breaks in eukaryotic cells. Science 2006, 313, 848-851. [CrossRef]

108. Wang, T.C.; Goldenring, J.R.; Dangler, C.; Ito, S.; Mueller, A.; Jeon, W.K.; Koh, T.J.; Fox, J.G. Mice lacking secretory phospho-lipase A 2 show altered apoptosis and differentiation with Helicobacterfelis infection. Gastroenterology 1998, 114, 675-689. [CrossRef]

109. Rakoff-Nahoum, S.; Medzhitov, R. Toll-like receptors and cancer. Nat. Rev. Cancer 2008, 9, 57-63. [CrossRef]

110. Thomas, R.M.; Jobin, C. The microbiome and cancer: Is the 'oncobiome'mirage real? Trends Cancer 2015, 1, 24-35. [CrossRef]

111. Urbaniak, C.; Cummins, J.; Brackstone, M.; Macklaim, J.M.; Gloor, G.B.; Baban, C.K.; Scott, L.; O’Hanlon, D.M.; Burton, J.P.; Francis, K.P.; et al. Microbiota of Human Breast Tissue. Appl. Environ. Microbiol. 2014, 80, 3007-3014. [CrossRef] [PubMed]

112. Urbaniak, C.; Gloor, G.B.; Brackstone, M.; Scott, L.; Tangney, M.; Reid, G. The Microbiota of Breast Tissue and Its Association with Breast Cancer. Appl. Environ. Microbiol. 2016, 82, 5039-5048. [CrossRef] [PubMed]

113. Yu, A.-Q.; Li, L. The Potential Role of Probiotics in Cancer Prevention and Treatment. Nutr. Cancer 2016, 68, 535-544. [CrossRef]

114. Ghosh, T.; Beniwal, A.; Semwal, A.; Navani, N.K. Mechanistic insights into probiotic properties of lactic acid bacteria associ-ated with ethnic fermented dairy products. Front. Microbiol. 2019, 10, 502. [CrossRef] [PubMed]

115. Oyetayo, V.O.; Oyetayo, F.L. Potential of probiotics as biotherapeutic agents targeting the innate immune system. Afr. J. Biotechnol. 2005, 4, 123-127.

116. Ohata, H.; Kitauchi, S.; Yoshimura, N.; Mugitani, K.; Iwane, M.; Nakamura, H.; Yoshikawa, A.; Yanaoka, K.; Arii, K.; Tamai, H.; et al. Progression of chronic atrophic gastritis associated with Helicobacter pylori infection increases risk of gastric can-cer. Int. J. Cancer 2004, 109, 138-143. [CrossRef]

117. Kho, Z.Y.; Lal, S.K. The Human Gut Microbiome - A Potential Controller of Wellness and Disease. Front. Microbiol. 2018, 9 , 1835. [CrossRef]

118. Ahn, J.; Yang, L.; Paster, B.J.; Ganly, I.; Morris, L.; Pei, Z.; Hayes, R.B. Oral Microbiome Profiles: 16S rRNA Pyrosequencing and Microarray Assay Comparison. PLoS ONE 2011, 6, e22788. [CrossRef]

119. Olsen, I. Yilmaz, Özlem Possible role of Porphyromonas gingivalis in orodigestive cancers. J. Oral Microbiol. 2019, 11, 1563410. [CrossRef]

120. Yu, G.; Gail, M.H.; Shi, J.; Klepac-Ceraj, V.; Paster, B.J.; Dye, B.A.; Wang, G.Q.; Wei, W.Q.; Fan, J.H.; Qiao, Y.L.; et al. Associa-tion between upper digestive tract microbiota and cancer-predisposing states in the esophagus and stomach. Cancer Epidemi-ol. Prev. Biomark 2014, 23, 735-741. [CrossRef]

121. D'Souza, G.; Kreimer, A.R.; Viscidi, R.; Pawlita, M.; Fakhry, C.; Koch, W.M.; Westra, W.H.; Gillison, M.L. Case-Control Study of Human Papillomavirus and Oropharyngeal Cancer. N. Engl. J. Med. 2007, 356, 1944-1956. [CrossRef] [PubMed] 
122. Nagy, K.; Sonkodi, I.; Szöke, I.; Nagy, E.; Newman, H. The microflora associated with human oral carcinomas. Oral Oncol. 1998, 34, 304-308. [CrossRef]

123. Gupta, H.; Youn, G.S.; Shin, M.J.; Suk, K.T. Role of Gut Microbiota in Hepatocarcinogenesis. Microorganisms $2019,7,121$. [CrossRef] [PubMed]

124. Sharpton, S.R.; Maraj, B.; Harding-Theobald, E.; Vittinghoff, E.; Terrault, N.A. Gut microbiome-targeted therapies in nonal-coholic fatty liver disease: A systematic review, meta-analysis, and meta-regression. Am. J. Clin. Nutr. 2019, 110, 139-149. [CrossRef]

125. Killian, M.; Chapple, I.L.C.; Hannig, M.; Marsh, P.D.; Meuric, V.; Pedersen, A.M.L.; Tonetti, M.S.; Wade, W.G.; Zaura, E. The oral microbiome-An update for oral healthcare professionals. Br. Dent. J. 2016, 221, 657-666. [CrossRef]

126. Younossi, Z.M. Non-alcoholic fatty liver disease-A global public health perspective. J. Hepatol. 2019, 70, 531-544. [CrossRef]

127. Araujo, A.R.; Rosso, N.; Bedogni, G.; Tiribelli, C.; Bellentani, S. Global epidemiology of non-alcoholic fatty liver dis-ease/nonalcoholic steatohepatitis: What we need in the future. Liver Int. 2018, 38, 47-51. [CrossRef]

128. Brunt, E.M.; Wong, V.W.S.; Nobili, V.; Day, C.P.; Sookoian, S.; Maher, J.J.; Bugianesi, E.; Sirlin, C.B.; Neuschwander-Tetri, B.A.; Rinella, M.E. Nonalcoholic fatty liver disease. Nat. Rev. Dis. Primers 2015, 1, 1-22. [CrossRef]

129. Zhou, R.; Fan, X.; Schnabl, B. Role of the intestinal microbiome in liver fibrosis development and new treatment strategies. Transl. Res. 2019, 209, 22-38. [CrossRef]

130. De Palma, G.; Nadal, I.; Collado, M.C.; Sanz, Y. Effects of a gluten-free diet on gut microbiota and immune function in healthy adult human subjects. Br. J. Nutr. 2009, 102, 1154-1160. [CrossRef]

131. Haran, J.P.; Bhattarai, S.K.; Foley, S.E.; Dutta, P.; Ward, D.V.; Bucci, V.; McCormick, B.A. Alzheimer's Disease Microbiome Is Associated with Dysregulation of the Anti-Inflammatory P-Glycoprotein Pathway. mBio 2019, 10, e00632-19. [CrossRef] [PubMed]

132. Mahmoudiandehkordi, S.; Arnold, M.; Nho, K.; Ahmad, S.; Jia, W.; Xie, G.; Louie, G.; Kueider-Paisley, A.; Moseley, M.A.; Thompson, J.W.; et al. Altered bile acid profile associates with cognitive impairment in Alzheimer's disease-An emerging role for gut microbiome. Alzheimer's Dement. 2019, 15, 76-92. [CrossRef] [PubMed]

133. Borrelli, A.; Bonelli, P.; Tuccillo, F.M.; Goldfine, I.D.; Evans, J.L.; Buonaguro, F.M.; Mancini, A. Role of gut microbiota and oxidative stress in the progression of non-alcoholic fatty liver disease to hepatocarcinoma: Current and innovative thera-peutic approaches. Redox biol. 2018, 15, 467-479. [CrossRef] [PubMed]

134. Betrapally, N.S.; Gillevet, P.M.; Bajaj, J.S. Changes in the intestinal microbiome and alcoholic and nonalcoholic liver diseas-es: Causes or effects? Gastroenterology 2016, 150, 1745-1755. [CrossRef]

135. Schwimmer, J.B.; Johnson, J.S.; Angeles, J.E.; Behling, C.; Belt, P.H.; Borecki, I.; Bross, C.; Durelle, J.; Goyal, N.P.; Hamilton, G.; et al. Microbiome signatures associated with steatohepatitis and moderate to severe fibrosis in children with nonalco-holic fatty liver disease. Gastroenterology 2019, 157, 1109-1122. [CrossRef]

136. Waterboer, T.; Dondog, B.; Michael, K.M.; Michel, A.; Schmitt, M.; Vaccarella, S.; Franceschi, S.; Clifford, G.; Pawlita, M. Dried Blood Spot Samples for Seroepidemiology of Infections with Human Papillomaviruses, Helicobacter pylori, Hepatitis C Virus, and JC Virus. Cancer Epidemiol. Biomark. Prev. 2012, 21, 287-293. [CrossRef]

137. Jia, W.; Xie, G.; Jia, W. Bile Acid-microbiota crosstalk in gastrointestinal inflammation and carcinogenesis. Nat. Rev. Gastroenterol. Hepatol. 2018, 15, 111. [CrossRef]

138. Peck, S.C.; Denger, K.; Burrichter, A.; Irwin, S.M.; Balskus, E.P.; Schleheck, D. A glycyl radical enzyme enables hydrogen sulfide production by the human intestinal bacterium Bilophilawadsworthia. Proc. Natl. Acad. Sci. USA 2019, 116, 3171-3176. [CrossRef]

139. Ji, S.; Choi, Y.S. Bacterial invasion and persistence: Critical events in the pathogenesis of periodontitis? J. Periodontal Res. 2014, 50, 570-585. [CrossRef]

140. Anand, P.; Kunnumakara, A.B.; Sundaram, C.; Harikumar, K.B.; Tharakan, S.T.; Lai, O.S.; Sung, B.; Aggarwal, B.B. Cancer is a Preventable Disease that Requires Major Lifestyle Changes. Pharm. Res. 2008, 25, 2097-2116. [CrossRef]

141. Hounsome, N.; Tomos, D.; Edwards-Jones, G. Plant Metabolites and Nutritional Quality of Vegetables. J. Food Sci. 2008, 73, R48-R65. [CrossRef] [PubMed]

142. LeBlanc, J.G.; Chain, F.; Martín, R.; Bermudez-Humaran, L.G.; Courau, S.; Langella, P. Beneficial effects on host energy metabolism of short-chain fatty acids and vitamins produced by commensal and probiotic bacteria. Microb. Cell Factories 2017, $16,1-10$.

143. Sanders, M.E.; Klaenhammer, T.R. Invited Review: The Scientific Basis of Lactobacillus acidophilus NCFM Functionality as a Probiotic. J. Dairy Sci. 2001, 84, 319-331. [CrossRef]

144. Im, E.; Pothoulakis, C. Recent advances in Saccharomyces boulardii research. Gastroentérologie Clinique et Biologique 2010, 34, S62-S70. [CrossRef]

145. Roderburg, C.; Luedde, T. The role of the gut microbiome in the development and progression of liver cirrhosis and hepa-tocellular carcinoma. Gut Microbes 2014, 5, 441-445. [CrossRef]

146. Yu, L.X.; Schwabe, R.F. The gut microbiome and liver cancer: Mechanisms and clinical translation. Nat. Rev. Gastroenterol. Hepatol. 2017, 14, 527. [CrossRef]

147. Peggs, K.S.; Quezada, S.A.; Allison, J.P. Cancer immunotherapy: Co-stimulatory agonists and co-inhibitory antagonists. Clin. Exp. Immunol. 2009, 157, 9-19. [CrossRef]

148. Pardoll, D.M. The blockade of immune checkpoints in cancer immunotherapy. Nat. Rev. Cancer 2012, 12, 252-264. [CrossRef]

149. Topalian, S.L.; Drake, C.G.; Pardoll, D.M. Immune checkpoint blockade: A common denominator approach to cancer thera-py. Cancer Cell 2015, 27, 450-461. [CrossRef] 
150. Mazzarella, L.; Duso, B.A.; Trapani, D.; Belli, C.; D’Amico, P.; Ferraro, E.; Viale, G.; Curigliano, G. The evolving landscape of 'next-generation'immune checkpoint inhibitors: A review. Eur. J. Cancer 2019, 117, 14-31. [CrossRef]

151. Huang, J.; Jiang, Z.; Wang, Y.; Fan, X.; Cai, J.; Yao, X.; Liu, L.; Huang, J.; He, J.; Xie, C.; et al. Modulation of gut microbiota to over-come resistance to immune checkpoint blockade in cancer immunotherapy. Curr. Opin. Pharmacol. 2020, 54, 1-10. [CrossRef] [PubMed]

152. Lengfelder, I.; Sava, I.G.; Hansen, J.J.; Kleigrewe, K.; Herzog, J.; Neuhaus, K.; Hofmann, T.; Sartor, R.B.; Haller, D. Complex Bacterial Consortia Reprogram the Colitogenic Activity of Enterococcus faecalis in a Gnotobiotic Mouse Model of Chronic, Immune-Mediated Colitis. Front. Immunol. 2019, 10, 1420. [CrossRef] [PubMed]

153. Paul, G.; Khare, V.; Gasche, C. Inflamed gut mucosa: Downstream of interleukin-10. Eur. J. Clin. Investig. 2012, 42, 95-109. [CrossRef] [PubMed]

154. Kim, S.V.; Xiang, W.V.; Kwak, C.; Yang, Y.; Lin, X.W.; Ota, M.; Sarpel, U.; Rifkin, D.B.; Xu, R.; Littman, D.R. GPR15-Mediated Homing Controls Immune Homeostasis in the Large Intestine Mucosa. Science 2013, 340, 1456-1459. [CrossRef]

155. Sopta, M.L. Toll Like Receptors (Tlr) in Autoimmune Diseases and Atherosclerosis. Ph.D. Thesis, School of Medicine, University of Zagreb, Zagreb, Croatia, 2016.

156. Alexander, J.L.; Wilson, I.D.; Teare, J.; Marchesi, J.R.; Nicholson, J.K.; Kinross, J.M. Gut microbiota modulation of chemo-therapy efficacy and toxicity. Nat. Rev. Gastroenterol. Hepatol. 2017, 14, 356-365. [CrossRef]

157. Ma, W.; Mao, Q.; Xia, W.; Dong, G.; Yu, C.; Jiang, F. Gut Microbiota Shapes the Efficiency of Cancer Therapy. Front. Microbiol. 2019, 10, 1050. [CrossRef]

158. Sharma, A.; Rath, A.K.; Chaudhary, A.P.; Thakar, A.; Mohanti, B.K.; Bahadur, S. Lactobacillus brevis CD2 lozenges reduce radi-ation- and chemotherapy-induced mucositis in patients with head and neck cancer: A randomized double-blind placebocontrolled study. Eur. J. Cancer 2012, 48, 875-881. [CrossRef]

159. Helmink, B.A.; Khan, M.A.W.; Hermann, A.; Gopalakrishnan, V.; Wargo, J.A. The microbiome, cancer, and cancer therapy. Nat. Med. 2019, 25, 377-388. [CrossRef]

160. Gopalakrishnan, V.; Helmink, B.A.; Spencer, C.N.; Reuben, A.; Wargo, J.A. The Influence of the Gut Microbiome on Can-cer, Immunity, and Cancer Immunotherapy. Cancer Cell 2018, 33, 570-580. [CrossRef]

161. Iida, N.; Dzutsev, A.; Stewart, C.A.; Smith, L.; Bouladoux, N.; Weingarten, R.A.; Molina, D.A.; Salcedo, R.; Back, T.; Cramer, S.; et al. Commensal Bacteria Control Cancer Response to Therapy by Modulating the Tumor Microenvironment. Science 2013, 342, 967-970. [CrossRef]

162. Paulos, C.M.; Wrzesinski, C.; Kaiser, A.; Hinrichs, C.S.; Chieppa, M.; Cassard, L.; Palmer, D.C.; Boni, A.; Muranski, P.; Yu, Z.; et al. Microbial translocation augments the function of adoptively transferred self/ tumor-specific CD8+ T cells via TLR4 sig-naling. J. Clin. Investig. 2007, 117, 2197-2204. [CrossRef] [PubMed]

163. Chaput, N.; Lepage, P.; Coutzac, C.; Soularue, E.; Le Roux, K.; Monot, C.; Boselli, L.; Routier, E.; Cassard, L.; Collins, M.; et al. Baseline gut microbiota predicts clinical response and colitis in metastatic melanoma patients treated with ipilimumab. Ann. Oncol. 2017, 28, 1368-1379. [CrossRef] [PubMed]

164. Jenq, R.R.; Taur, Y.; Devlin, S.M.; Ponce, D.M.; Goldberg, J.D.; Ahr, K.F.; Littmann, E.R.; Ling, L.; Gobourne, A.C.; Miller, L.C.; et al. Intestinal Blautia is associated with reduced death from graft-versus-host disease. Biol. Blood Marrow Transpl. 2015, 21, 1373-1383. [CrossRef] [PubMed]

165. Dubin, K.; Callahan, M.K.; Ren, B.; Khanin, R.; Viale, A.; Ling, L.; No, D.; Gobourne, A.; Littmann, E.; Huttenhower, C.; et al. Intestinal microbiome analyses identify melanoma patients at risk for checkpointblockade-induced colitis. Nat. Commun. 2016, 7, 0391. [CrossRef]

166. Sivan, A.; Corrales, L.; Hubert, N.; Williams, J.B.; Aquino-Michaels, K.; Earley, Z.M.; Benyamin, F.W.; Lei, Y.M.; Jabri, B.; Alegre, M.-L.; et al. Commensal Bifidobacterium promotes antitumor immunity and facilitates anti-PD-L1 efficacy. Science 2015, 350, 1084-1089. [CrossRef]

167. Vétizou, M.; Pitt, J.M.; Daillère, R.; Lepage, P.; Waldschmitt, N.; Flament, C.; Rusakiewicz, S.; Routy, B.; Roberti, M.P.; Duong, C.P.M.; et al. Anticancer immunotherapy by CTLA-4 blockade relies on the gut microbiota. Science 2015, 350, 1079-1084. [CrossRef]

168. Peled, J.; Devlin, S.M.; Staffas, A.; Lumish, M.; Khanin, R.; Littmann, E.R.; Ling, L.; Kosuri, S.; Maloy, M.; Slingerland, J.B.; et al. Intestinal Microbiota and Relapse After Hematopoietic-Cell Transplantation. J. Clin. Oncol. 2017, 35, 1650-1659. [CrossRef]

169. Frankel, A.E.; Coughlin, L.A.; Kim, J.; Froehlich, T.W.; Xie, Y.; Frenkel, E.P.; Koh, A.Y. Metagenomic Shotgun Sequencing and Unbiased Metabolomic Profiling Identify Specific Human Gut Microbiota and Metabolites Associated with Immune Checkpoint Therapy Efficacy in Melanoma Patients. Neoplasia 2017, 19, 848-855. [CrossRef]

170. Matson, V.; Fessler, J.; Bao, R.; Chongsuwat, T.; Zha, Y.; Alegre, M.-L.; Luke, J.J.; Gajewski, T.F. The commensal microbiome is associated with anti-PD-1 efficacy in metastatic melanoma patients. Science 2018, 359, 104-108. [CrossRef]

171. Gopalakrishnan, V.; Spencer, C.N.; Nezi, L.; Reuben, A.; Andrews, M.C.; Karpinets, T.V.; Prieto, P.A.; Vicente, D.; Hoffman, K.; Wei, S.C.; et al. Gut microbiome modulates response to anti-PD-1 immunotherapy in melanoma patients. Science 2018, 359, 97-103. [CrossRef]

172. Routy, B.; Le Chatelier, E.; DeRosa, L.; Duong, C.P.M.; Alou, M.T.; Daillère, R.; Fluckiger, A.; Messaoudene, M.; Rauber, C.; Roberti, M.P.; et al. Gut microbiome influences efficacy of PD-1-based immunotherapy against epithelial tumors. Science 2018, 359, 91-97. [CrossRef] [PubMed] 
173. Geller, L.T.; Barzily-Rokni, M.; Danino, T.; Jonas, O.H.; Shental, N.; Nejman, D.; Gavert, N.; Zwang, Y.; Cooper, Z.A.; Shee, K.; et al. Potential role of intratumor bacteria in mediating tumor resistance to the chemotherapeutic drug gemcitabine. Science 2017, 357, 1156-1160. [CrossRef] [PubMed]

174. Viaud, S.; Saccheri, F.; Mignot, G.; Yamazaki, T.; Daillère, R.; Hannani, D.; Enot, D.P.; Pfirschke, C.; Engblom, C.; Pittet, M.J.; et al. The Intestinal Microbiota Modulates the Anticancer Immune Effects of Cyclophosphamide. Science 2013, 342, 971-976. [CrossRef] [PubMed]

175. Sansom, D.M.; Walker, L.S. The role of CD28 and cytotoxic T-lymphocyte antigen-4 (CTLA-4) in regulatory T-cell biology. Immunol. Rev. 2006, 212, 131-148. [CrossRef]

176. Gasser, M.; Waaga-Gasser, A.M. Therapeutic antibodies in cancer therapy. In Protein Targeting Compounds; Springer: Berlin/Heidelberg, Germany, 2016; pp. 95-120.

177. Yi, M.; Qin, S.; Chu, Q.; Wu, K. The role of gut microbiota in immune checkpoint inhibitor therapy. HepatoBiliary Surg. Nutr. 2018, 7, 481-483. [CrossRef]

178. Seow, S.W.; Rahmat, J.N.B.; Mohamed, A.A.K.; Mahendran, R.; Lee, Y.K.; Bay, B.H. Lactobacillus species is more cytotoxic to human bladder cancer cells than Mycobacterium Bovis (bacillus Calmette-Guerin). J. Urol. 2002, 168, 2236-2239. [CrossRef]

179. Seidel, J.A.; Otsuka, A.; Kabashima, K. Anti-PD-1 and Anti-CTLA-4 Therapies in Cancer: Mechanisms of Action, Efficacy, and Limitations. Front. Oncol. 2018, 8, 86. [CrossRef]

180. Zitvogel, L.; Ma, Y.; Raoult, D.; Kroemer, G.; Gajewski, T.F. The microbiome in cancer immunotherapy: Diagnostic tools and therapeutic strategies. Science 2018, 359, 1366-1370. [CrossRef]

181. Puzanov, I.; Diab, A.; Abdallah, K.; Bingham, C.O.; Brogdon, C.; Dadu, R.; Hamad, L.; Kim, S.; Lacouture, M.E.; LeBoeuf, N.R.; et al. Managing toxicities associated with immune checkpoint inhibitors: Consensus recommendations from the Socie-ty for Immunotherapy of Cancer (SITC) Toxicity Management Working Group. J. Immunother. Cancer 2017, 5, 1-28. [CrossRef]

182. De La Cuesta-Zuluaga, J.; Mueller, N.T.; Corrales-Agudelo, V.; Velásquez-Mejía, E.P.; Carmona, J.A.; Abad, J.M.; Escobar, J.S. Metformin is associated with higher relative abundance of mucin-degrading Akkermansia muciniphila and several short-chain fatty acid-producing microbiota in the gut. Diabetes Care 2017, 40, 54-62. [CrossRef]

183. Anfossi, S.; Calin, G.A. Gut microbiota: A new player in regulating immune- and chemo-therapy efficacy. Cancer Drug Resist. 2020, 3, 356-370. [CrossRef] [PubMed]

184. York, A. Gut microbiota sways response to cancer immunotherapy. Nat. Rev. Genet. 2018, 16, 121. [CrossRef] [PubMed]

185. Cooke, K.R.; Olkiewicz, K.; Erickson, N.; Ferrara, J.L. The role of endotoxin and the innate immune response in the pathophysiology of acute graft versus host disease. J. Endotoxin Res. 2002, 8, 441-448. [CrossRef] [PubMed]

186. Penack, O.; Holler, E.; van den Brink, M.R. Graft-versus-host disease: Regulation by microbe-associated molecules and in-nate immune receptors. Blood J. Am. Soc. Hematol. 2010, 115, 1865-1872. [CrossRef]

187. Dasgupta, S.; Erturk-Hasdemir, D.; Ochoa-Reparaz, J.; Reinecker, H.-C.; Kasper, D.L. Plasmacytoid Dendritic Cells Mediate Anti-inflammatory Responses to a Gut Commensal Molecule via Both Innate and Adaptive Mechanisms. Cell Host Microbe 2014, 15, 413-423. [CrossRef]

188. Stingele, F.; Corthésy, B.; Kusy, N.; Porcelli, S.A.; Kasper, D.L.; Tzianabos, A.O. Zwitterionic Polysaccharides Stimulate T Cells with No Preferential V $\beta$ Usage and Promote Anergy, Resulting in Protection against Experimental Abscess Formation. J. Immunol. 2004, 172, 1483-1490. [CrossRef]

189. Cheng, H.-Y.; Ning, M.-X.; Chen, D.-K.; Ma, W.-T. Interactions Between the Gut Microbiota and the Host Innate Immune Response Against Pathogens. Front. Immunol. 2019, 10, 607. [CrossRef]

190. Thomas, A.M.; Jesus, E.C.; Lopes, A.; Aguiar, S.J.; Begnami, M.D.; Rocha, R.M.; Carpinetti, P.A.; Camargo, A.A.; Hoffmann, C.; Freitas, H.C.; et al. Tissue-Associated Bacterial Alterations in Rectal Carcinoma Patients Revealed by 16S rRNA Com-munity Profiling. Front. Cell. Infect. Microbiol. 2016, 6, 179. [CrossRef]

191. Colosimo, D.A.; Kohn, J.A.; Luo, P.M.; Piscotta, F.J.; Han, S.M.; Pickard, A.J.; Rao, A.; Cross, J.R.; Cohen, L.J.; Brady, S.F. Mapping Interactions of Microbial Metabolites with Human G-Protein-Coupled Receptors. Cell Host Microbe 2019, 26, 273-282. [CrossRef]

192. Viaud, S.; Daillere, R.; Boneca, I.G.; Lepage, P.; Langella, P.; Chamaillard, M.; Pittet, M.J.; Ghiringhelli, F.; Trinchieri, G.; Goldszmid, R.; et al. Gut microbiome and anticancer immune response: Really hot Sh*t! Cell Death Differ. 2014, 22, 199-214. [CrossRef]

193. Atarashi, K.; Tanoue, T.; Shima, T.; Imaoka, A.; Kuwahara, T.; Momose, Y.; Cheng, G.; Yamasaki, S.; Saito, T.; Ohba, Y.; et al. Induction of colonic regulatory T cells by indigenous clostridium species. Science 2011, 331, 337-341. [CrossRef] [PubMed]

194. Mazmanian, S.K.; Liu, C.H.; Tzianabos, A.O.; Kasper, D.L. An Immunomodulatory Molecule of Symbiotic Bacteria Directs Maturation of the Host Immune System. Cell 2005, 122, 107-118. [CrossRef] [PubMed]

195. Daillère, R.; Vétizou, M.; Waldschmitt, N.; Yamazaki, T.; Isnard, C.; Poirier-Colame, V.; Duong, C.P.; Flament, C.; Lepage, P.; Roberti, M.P.; et al. Enterococcus hirae and Barnesiellaintestinihominis facilitate cyclophosphamide-induced therapeutic immunomodulatory effects. Immunity 2016, 45, 931-943. [CrossRef] [PubMed]

196. Mao, K.; Baptista, A.P.; Tamoutounour, S.; Zhuang, L.; Bouladoux, N.; Martins, A.J.; Huang, Y.; Gerner, M.Y.; Belkaid, Y.; Germain, R.N. Innate and adaptive lymphocytes sequentially shape the gut microbiota and lipid metabolism. Nat. Cell Biol. 2018, 554, 255-259. [CrossRef] [PubMed]

197. Pitt, J.M.; Vétizou, M.; Waldschmitt, N.; Kroemer, G.; Chamaillard, M.; Boneca, I.G.; Zitvogel, L. Fine-tuning cancer immunotherapy: Optimizing the gut microbiome. Cancer Res. 2016, 76, 4602-4607. 
198. Miller, P.L.; Carson, T.L. Mechanisms and microbial influences on CTLA-4 and PD-1-based immunotherapy in the treatment of cancer: A narrative review. Gut Pathog. 2020, 12, 1-10. [CrossRef]

199. Schönrich, G.; Raftery, M.J. The PD-1/PD-L1 Axis and Virus Infections: A Delicate Balance. Front. Cell. Infect. Microbiol. 2019, 9 , 207. [CrossRef]

200. Lee, H.T.; Lee, S.H.; Heo, Y.-S. Molecular Interactions of Antibody Drugs Targeting PD-1, PD-L1, and CTLA-4 in ImmunoOncology. Molecules 2019, 24, 1190. [CrossRef]

201. Harris, E. Immunotherapeutics for the treatment of prostate cancer: A patent landscape based on key therapeutic mechanisms of actions. Pharm. Pat. Anal. 2018, 7, 47-57. [CrossRef]

202. Mager, L.F.; Burkhard, R.; Pett, N.; Cooke, N.C.A.; Brown, K.; Ramay, H.; Paik, S.; Stagg, J.; Groves, R.A.; Gallo, M.; et al. Microbiome-derived inosine modulates response to checkpoint inhibitor immunotherapy. Science 2020, 369, 1481-1489. [CrossRef]

203. Mager, L.F.; Burkhard, R.; Cooke, N.C.; Brown, K.; Ramay, H.; Paik, S.; Stagg, J.; Groves, R.A.; Gallo, M.; Lewis, I.A.; et al. Immunotherapy efficacy in colorectal cancer is dependent on activation of a microbial-metabolite-immune circuit. BioRxiv 2020. [CrossRef]

204. Dredge, K.; Marriott, B.J.; Todryk, S.M.; Dalgleish, A.G. Adjuvants and the promotion of Th1-type cytokines in tumour immunotherapy. Cancer Immunol. Immunother. 2002, 51, 521-531. [CrossRef] [PubMed]

205. Gilbert, J.A.; Blaser, M.J.; Caporaso, J.G.; Jansson, J.K.; Lynch, S.V.; Knight, R. Current understanding of the human microbiome. Nat. Med. 2018, 24, 392-400. [CrossRef] [PubMed]

206. Yi, M.; Jiao, D.; Qin, S.; Chu, Q.; Li, A.; Wu, K. Manipulating Gut Microbiota Composition to Enhance the Therapeutic Effect of Cancer Immunotherapy. Integr Cancer Ther. 2019. [CrossRef] [PubMed]

207. Oku, S.; Takeshita, T.; Futatsuki, T.; Kageyama, S.; Asakawa, M.; Mori, Y.; Miyamoto, T.; Hata, J.; Ninomiya, T.; Kashiwazaki, H.; et al. Disrupted tongue microbiota and detection of nonindigenous bacteria on the day of allogeneic hematopoietic stem cell transplantation. PLoS Pathog. 2020, 16, e1008348. [CrossRef] [PubMed]

208. Mahmoud, H.K.; Elhaddad, A.M.; Fahmy, O.A.; Samra, M.A.; Abdelfattah, R.M.; El-Nahass, Y.H.; Fathy, G.M.; Abdelhady, M.S. Allogeneic hematopoietic stem cell transplantation for non-malignant hematological disorders. J. Adv. Res. 2015, 6, 449-458. [CrossRef] [PubMed]

209. Liu, Q.; Fan, Z.-P.; Wu, M.-Q.; Sun, J.; Wu, X.-L.; Xu, D.; Jiang, Q.-L.; Zhang, Y.; Huang, F.; Wei, Y.-Q.; et al. Allo-HSCT for acute leukemia of ambiguous lineage in adults: The comparison between standard conditioning and intensified conditioning regimens. Ann. Hematol. 2012, 92, 679-687. [CrossRef]

210. Taur, Y.; Xavier, J.B.; Lipuma, L.; Ubeda, C.; Goldberg, J.; Gobourne, A.; Lee, Y.J.; Dubin, K.A.; Socci, N.D.; Viale, A.; et al. Intestinal Domination and the Risk of Bacteremia in Patients Undergoing Allogeneic Hematopoietic Stem Cell Transplantation. Clin. Infect. Dis. 2012, 55, 905-914. [CrossRef]

211. Li, L. Infectious Microecology in Liver Disease. In Infectious Microecology; Springer: Berlin/Heidelberg, Germany, 2014; pp. 317-332.

212. Ashraf, R.; Shah, N.P. Selective and differential enumerations of Lactobacillus delbrueckii subsp. bulgaricus, Streptococcus thermophilus, Lactobacillus acidophilus, Lactobacillus casei and Bifidobacterium spp. in yoghurt-A review. Int. J. Food Microbiol. 2011, 149, 194-208. [CrossRef]

213. Eslami-S, Z.; Majidzadeh-A, K.; Halvaei, S.; Babapirali, F.; Esmaeili, R. Microbiome and Breast Cancer: New Role for an Ancient Population. Front. Oncol. 2020, 10, 120. [CrossRef]

214. Tharmaraj, N.; Shah, N.P. Survival of Lactobacillus acidophilus, Lactobacillus paracasei subsp. paracasei, Lactobacillus rhamnosus, Bifidobacterium animalis and Propionibacterium in cheese-based dips and the suitability of dips as effective carriers of probiotic bacteria. Int. Dairyj. 2004, 14, 1055-1066. [CrossRef]

215. Ambalam, P.; Raman, M.; Purama, R.K.; Doble, M. Probiotics, prebiotics and colorectal cancer prevention. Best Pr. Res. Clin. Gastroenterol. 2016, 30, 119-131. [CrossRef] [PubMed]

216. Lin, C.; Cai, X.; Zhang, J.; Wang, W.; Sheng, Q.; Hua, H.; Zhou, X. Role of Gut Microbiota in the Development and Treatment of Colorectal Cancer. Digestion 2018, 100, 72-78. [CrossRef] [PubMed]

217. Deo, P.N.; Deshmukh, R. Oral microbiome: Unveiling the fundamentals. J. Oral Maxillofac. Pathol. 2019, 23, 122-128. [CrossRef]

218. Jones, S.E.; Versalovic, J. Probiotic Lactobacillus reuteri biofilms produce antimicrobial and anti-inflammatory factors. BMC Microbiol. 2009, 9, 1-9. [CrossRef]

219. Duran-Pinedo, A.E.; Frias-Lopez, J. Beyond microbial community composition: Functional activities of the oral microbiome in health and disease. Microbes Infect. 2015, 17, 505-516. [CrossRef]

220. Jahrsdörfer, B.; Weiner, G.J. CpG oligodeoxynucleotides as immunotherapy in cancer. Updat. Cancer Ther. 2008, 3, 27-32. [CrossRef]

221. Wynn, T.A.; Aliberti, J.; Hoffmann, K.F.; Jankovic, D.; Feng, C.G.; Kullberg, M.C.; Sher, A. Experimental models for the analysis of IL-10 function. In Interleukin-10; Marincola, F.M., Ed.; Taylor \& Francis: Abingdon, UK, 2006. [CrossRef]

222. Donnelly, R.P.; Dickensheets, H.; Finbloom, D.S. The Interleukin-10 Signal Transduction Pathway and Regulation of Gene Expression in Mononuclear Phagocytes. J. Interf. Cytokine Res. 1999, 19, 563-573. [CrossRef]

223. Ni, G.; Wang, T.; Walton, S.F.; Zhu, B.; Chen, S.; Wu, X.; Wang, Y.; Wei, M.Q.; Liu, X.S. Manipulating IL-10 signalling blockade for better immunotherapy. Cell. Immunol. 2015, 293, 126-129. [CrossRef]

224. Rigopoulou, E.I.; Abbott, W.G.; Haigh, P.; Naoumov, N.V. Blocking of interleukin-10 receptor-A novel approach to stimulate T-helper cell type 1 responses to hepatitis C virus. Clin. Immunol. 2005, 117, 57-64. [CrossRef] 
225. Adamus, T.; Kortylewski, M. The revival of CpG oligonucleotide-based cancer immunotherapies. Wspótczesna Onkol. 2018, 2018, 56-60. [CrossRef] [PubMed]

226. Deng, H.; Zhang, Z. The application of nanotechnology in immune checkpoint blockade for cancer treatment. J. Control. Release 2018, 290, 28-45. [CrossRef] [PubMed]

227. Brandi, G.; Frega, G. Microbiota: Overview and Implication in Immunotherapy-Based Cancer Treatments. Int. J. Mol. Sci. 2019, 20, 2699. [CrossRef] [PubMed]

228. June, C.H.; O'Connor, R.S.; Kawalekar, O.U.; Ghassemi, S.; Milone, M.C. CAR T cell immunotherapy for human cancer. Science 2018, 359, 1361-1365. [CrossRef]

229. Kershaw, M.H.; Westwood, J.A.; Slaney, C.Y.; Darcy, P.K. Clinical application of genetically modified T cells in cancer therapy. Clin. Transl. Immunol. 2014, 3, e16. [CrossRef]

230. Shui, L.; Yang, X.; Li, J.; Yi, C.; Sun, Q.; Zhu, H. Gut microbiome as a potential factor for modulating resistance to cancer immunotherapy. Front. Immunol. 2019, 10. [CrossRef]

231. Kump, P.; Wurm, P.; Gröchenig, H.P.; Wenzl, H.; Petritsch, W.; Halwachs, B.; Wagner, M.; Stadlbauer, V.; Eherer, A.; Hoffmann, K.M.; et al. The taxonomic composition of the donor intestinal microbiota is a major factor influencing the efficacy of faecal microbiota transplantation in therapy refractory ulcerative colitis. Aliment. Pharmacol. Ther. 2018, 47, 67-77. [CrossRef]

232. Ooijevaar, R.; Van Beurden, Y.; Terveer, E.; Goorhuis, A.; Bauer, M.; Keller, J.; Mulder, C.; Kuijper, E. Update of treatment algorithms for Clostridium difficile infection. Clin. Microbiol. Infect. 2018, 24, 452-462. [CrossRef]

233. Perez, E.; Lee, C.H.; Petrof, E.O. A Practical Method for Preparation of Fecal Microbiota Transplantation. Adv. Struct. Saf. Stud. 2016, 9, 259-267. [CrossRef]

234. Zuo, T.; Wong, S.H.; Lam, K.; Lui, R.; Cheung, K.; Tang, W.; Ching, J.Y.L.; Chan, P.K.S.; Chan, M.C.-W.; Wu, J.C.Y.; et al. Bacteriophage transfer during faecal microbiota transplantation inClostridiumdifficileinfection is associated with treatment outcome. Gut 2017, 67, 634-643. [CrossRef]

235. Takahashi, K.; Nishida, A.; Fujimoto, T.; Fujii, M.; Shioya, M.; Imaeda, H.; Inatomi, O.; Bamba, S.; Andoh, A.; Sugimoto, M. Reduced Abundance of Butyrate-Producing Bacteria Species in the Fecal Microbial Community in Crohn's Disease. Digestion 2016, 93, 59-65. [CrossRef] [PubMed]

236. Spohn, S.N.; Young, V.B. Gastrointestinal Microbial Ecology with Perspectives on Health and Disease. In Physiology of the Gastrointestinal Tract; Elsevier: Amsterdam, The Netherlands, 2018; pp. 737-753.

237. Carabotti, M.; Scirocco, A.; Maselli, M.A.; Severi, C. The gut-brain axis: Interactions between enteric microbiota, central and enteric nervous systems. Ann. Gastroenterol. 2015, 28, 203-209. [PubMed]

238. Neuman, H.; Debelius, J.W.; Knight, R.; Koren, O. Microbial endocrinology: The interplay between the microbiota and the endocrine system. FEMS Microbiol. Rev. 2015, 39, 509-521. [CrossRef] [PubMed]

239. Sandrini, S.; Aldriwesh, M.; Alruways, M.; Freestone, P. Microbial endocrinology: Host-bacteria communication within the gut microbiome. J. Endocrinol. 2015, 225, R21-R34. [CrossRef] [PubMed]

240. Ceranowicz, P.; Warzecha, Z.; Dembinski, A. Peptidyl hormones of endocrine cells origin in the gut-Their discovery and physiological relevance. J. Physiol. Pharmacol. 2015, 66, 11-27. [PubMed]

241. Noureldein, M.H.; Eid, A.A. Gut microbiota and mTOR signaling: Insight on a new pathophysiological interaction. Microb. Pathog. 2018, 118, 98-104. [CrossRef]

242. Kar, S.K.; Jansman, A.J.; Benis, N.; Ramiro-Garcia, J.; Schokker, D.; Kruijt, L.; Stolte, E.H.; Taverne-Thiele, J.J.; Smits, M.A.; Wells, J.M. Dietary protein sources differentially affect microbiota, mTOR activity and transcription of mTOR signaling pathways in the small intestine. PLoS ONE 2017, 12, e0188282. [CrossRef]

243. Kim, S.; Jazwinski, S.M. The gut microbiota and healthy aging: A mini-review. Gerontology 2018, 64, 513-520. [CrossRef]

244. Yeh, C.F.; Chen, Y.H.; Liu, S.F.; Kao, H.L.; Wu, M.S.; Yang, K.C.; Wu, W.K. Mutual Interplay of Host Immune System and Gut Microbiota in the Immunopathology of Atherosclerosis. Int. J. Mol. Sci. 2020, 21, 8729. [CrossRef]

245. Thaiss, C.A.; Zmora, N.; Levy, M.; Elinav, E. The microbiome and innate immunity. Nature 2016, 535, 65-74. [CrossRef]

246. Round, J.L.; Mazmanian, S.K. The gut microbiota shapes intestinal immune responses during health and disease. Nat. Rev. Immunol. 2009, 9, 313-323. [CrossRef] [PubMed]

247. McDermott, A.J.; Huffnagle, G.B. The microbiome and regulation of mucosal immunity. Immunology 2014, 142, $24-31$. [CrossRef] [PubMed]

248. Qin, Y.; Wade, P.A. Crosstalk between the microbiome and epigenome: Messages from bugs. J. Biochem. 2018, 163, 105-112. [CrossRef] [PubMed]

249. Miller, M.B.; Bassler, B.L. Quorum sensing in bacteria. Annu. Rev. Microbiol. 2001, 55, 165-199. [CrossRef] [PubMed]

250. Ostaff, M.J.; Stange, E.F.; Wehkamp, J. Antimicrobial peptides and gut microbiota in homeostasis and pathology. EMBO Mol. Med. 2013, 5, 1465-1483. [CrossRef]

251. Jan, G.; Belzacq, A.S.; Haouzi, D.; Rouault, A.; Métivier, D.; Kroemer, G.; Brenner, C. Propionibacteria induce apoptosis of colorectal carcinoma cells via short-chain fatty acids acting on mitochondria. Cell Death Differ. 2002, 9, 179-188. [CrossRef]

252. Wei, W.; Sun, W.; Yu, S.; Yang, Y.; Ai, L. Butyrate production from high-fiber diet protects against lymphoma tumor. Leuk. Lymphoma 2016, 57, 2401-2408. [CrossRef] 
253. Paavonen, J.; Naud, P.; Salmerón, J.; Wheeler, C.M.; Chow, S.N.; Apter, D.; Kitchener, H.; Castellsague, X.; Teixeira, J.C.; Skinner, S.R.; et al. Efficacy of human papillomavirus (HPV)-16/18 AS04-adjuvanted vaccine against cervical infection and precancer caused by oncogenic HPV types (PATRICIA): Final analysis of a double-blind, randomised study in young women. Lancet 2009, 374, 301-314. [CrossRef]

254. Aranda, F.; Bloy, N.; Pesquet, J.; Petit, B.; Chaba, K.; Sauvat, A.; Kepp, O.; Khadra, N.; Enot, D.; Pfirschke, C.; et al. Immune-dependent antineoplastic effects of cisplatin plus pyridoxine in non-small-cell lung cancer. Oncogene 2015, 34, 3053-3062. [CrossRef]

255. Konishi, H.; Fujiya, M.; Tanaka, H.; Ueno, N.; Moriichi, K.; Sasajima, J.; Ikuta, K.; Akutsu, H.; Tanabe, H.; Kohgo, Y. Probioticderived ferrichrome inhibits colon cancer progression via JNK-mediated apoptosis. Nat. Commun. 2016, 7, 12365. [CrossRef]

256. Lenoir, M.; Del Carmen, S.; Cortes-Perez, N.G.; Lozano-Ojalvo, D.; Muñoz-Provencio, D.; Chain, F.; Langella, P.; de Moreno de LeBlanc, A.; LeBlanc, J.G.; Bermúdez-Humarán, L.G. Lactobacillus casei BL23 regulates Treg and Th17 T-cell populations and reduces DMH-associated colorectal cancer. J. Gastroenterol. 2016, 51, 862-873. [CrossRef] [PubMed]

257. Lee, J.W.; Shin, J.G.; Kim, E.H.; Kang, H.E.; Yim, I.B.; Kim, J.Y.; Joo, H.G.; Woo, H.J. Immunomodulatory and antitumor effects in vivo by the cytoplasmic fraction of Lactobacillus casei and Bifidobacterium longum. J. Vet. Sci. 2004, 5, 41-48. [CrossRef] [PubMed]

258. Baldwin, C.; Millette, M.; Oth, D.; Ruiz, M.T.; Luquet, F.M.; Lacroix, M. Probiotic Lactobacillus acidophilus and L. casei mix sensitize colorectal tumoral cells to 5-fluorouracil-induced apoptosis. Nutr. Cancer 2010, 62, 371-378. [CrossRef] [PubMed]

259. Takagi, A.; Ikemura, H.; Matsuzaki, T.; Sato, M.; Nomoto, K.; Morotomi, M.; Yokokura, T. Relationship between the in vitro response of dendritic cells to Lactobacillus and prevention of tumorigenesis in the mouse. J. Gastroenterol. 2008, 43, 661-669. [CrossRef] [PubMed]

260. McCarthy, E.F. The toxins of William, B. Coley and the treatment of bone and soft-tissue sarcomas. IOWA Orthop. J. 2006, 26, 154-158. [PubMed]

261. Nauts, H.C.; Swift, W.E.; Coley, B.L. The treatment of malignant tumors by bacterial toxins as developed by the late William, B.; Coley, M.D., reviewed in the light of modern research. Cancer Res. 1946, 6, 205-216.

262. Zbar, B.; Bernstein, I.; Tanaka, T.; Rapp, H.J. Tumor immunity produced by the intradermal inoculation of living tumor cells and living Mycobacterium bovis (strain BCG). Science 1970, 170, 1217-1218. [CrossRef]

263. Aso, Y.; Akazan, H. Prophylactic effect of a Lactobacillus casei preparation on the recurrence of superficial bladder cancer. BLP Study Group. Urol. Int. 1992, 49, 125-129. [CrossRef]

264. Hoesl, C.E.; Altwein, J.E. The probiotic approach: An alternative treatment option in urology. Eur. Urol. 2005, 47, 288-296. [CrossRef]

265. Stebbing, J.; Dalgleish, A.; Gifford-Moore, A.; Martin, A.; Gleeson, C.; Wilson, G.; Brunet, L.R.; Grange, J.; Mudan, S. An intrapatient placebo-controlled phase I trial to evaluate the safety and tolerability of intradermal IMM-101 in melanoma. Ann. Oncol. 2012, 23, 1314-1319. [CrossRef]

266. Dalgleish, A.G.; Stebbing, J.; Adamson, D.J.; Arif, S.S.; Bidoli, P.; Chang, D.; Cheeseman, S.; Diaz-Beveridge, R.; Fernandez-Martos, C.; Glynne-Jones, R.; et al. Randomised, open-label, phase II study of gemcitabine with and without IMM-101 for advanced pancreatic cancer. Br. J. Cancer. 2016, 115, 789-796. [CrossRef] [PubMed]

267. Toso, J.F.; Gill, V.J.; Hwu, P.; Marincola, F.M.; Restifo, N.P.; Schwartzentruber, D.J.; Sherry, R.M.; Topalian, S.L.; Yang, J.C.; Stock, F.; et al. Phase I study of the intravenous administration of attenuated Salmonella typhimurium to patients with metastatic melanoma. J. Clin. Oncol. 2002, 20, 142-152. [CrossRef] [PubMed]

268. Nemunaitis, J.; Cunningham, C.; Senzer, N.; Kuhn, J.; Cramm, J.; Litz, C.; Cavagnolo, R.; Cahill, A.; Clairmont, C.; Sznol, M. Pilot trial of genetically modified, attenuated Salmonella expressing the E. coli cytosine deaminase gene in refractory cancer patients. Cancer Gene Ther. 2003, 10, 737-744. [CrossRef] [PubMed]

269. Kramer, M.G.; Masner, M.; Ferreira, F.A.; Hoffman, R.M. Bacterial Therapy of Cancer: Promises, Limitations, and Insights for Future Directions. Front. Microbiol. 2018, 9, 16. [CrossRef] 